\title{
Arctic cold seeps in marine methane hydrate environments: impacts on shelf macrobenthic community structure offshore Svalbard
}

\author{
Emmelie K. L. Åström ${ }^{1, *}$, Michael L. Carroll ${ }^{1,2}$, William G. Ambrose Jr. ${ }^{1,3,4}$, \\ JoLynn Carroll ${ }^{1,2}$ \\ ${ }^{1}$ CAGE - Centre for Arctic Gas hydrate, Environment and Climate, Department of Geology, \\ UiT The Arctic University of Norway, 9037 Tromsø, Norway \\ ${ }^{2}$ Akvaplan-niva, FRAM - High North Research Centre for Climate and the Environment, 9296 Tromsø, Norway \\ ${ }^{3}$ Department of Biology, Bates College, Lewiston, Maine 04240, USA \\ ${ }^{4}$ Division of Polar Programs, National Science Foundation, Arlington, Virginia 22230, USA
}

\begin{abstract}
Cold seeps are locations where hydrocarbons emanate from the seabed, fueling chemoautotrophic production that may support macrofaunal communities via chemosymbiosis or trophic interactions. The recent discovery of offshore sub-seabed gas reservoirs and venting methane at the seabed in Svalbard $\left(75\right.$ to $\left.79^{\circ} \mathrm{N}\right)$ provides the context to examine the influence of cold seeps on macrofaunal community structure in the high-Arctic. We compared benthic macrofaunal community structure from cold-seep environments and paired control stations from 3 regionally distinct areas along the western Svalbard margin and the western Barents Sea. Specialized seep-related polychaetes (e.g. siboglinid tubeworms) were found at seep stations in the Barents Sea in high densities (up to 7272 ind. $\mathrm{m}^{-2}$ ). The presence of obligate seep-associated faunal taxa demonstrates that chemoautotrophic production, fueled by methane and sulfur, influences benthic communities at these seeps. Further, total biomass was significantly higher at seep-impacted stations compared to controls (mean = 20.7 vs. $9.8 \mathrm{~g}$ wet weight sample ${ }^{-1}$ ), regardless of region. Four methane seep-influenced samples showed clear indications of seep impact, with reduced diversity and with a few species dominating, compared to controls. Our results demonstrate that the effect of methane seeps on the Svalbard shelf benthic community are highly localized (i.e. meter scale), reflecting strong gradients associated with the point-source impacts of individual seeps. Regional differences and the restricted spatial extent of focused emissions likely drive the observed complexity and heterogeneity at Svalbard cold seeps. These results provide key base-
\end{abstract}

${ }^{*}$ Corresponding author: emmelie.k.astrom@uit.no

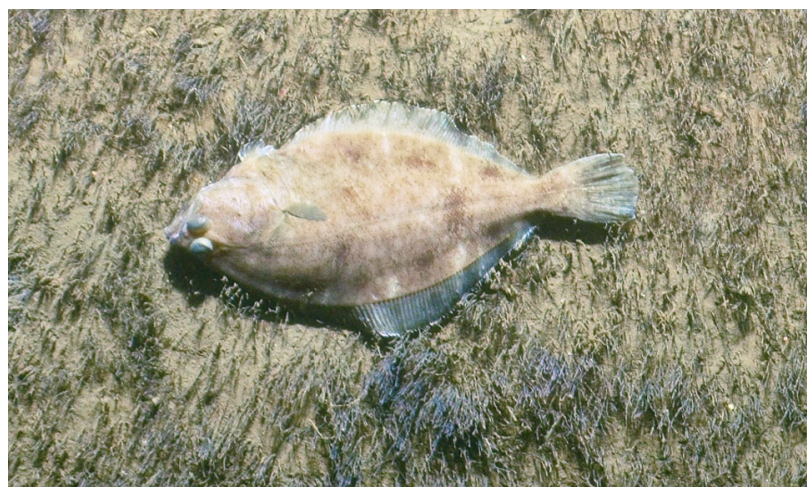

American plaice Hippoglossoides platessoides in a dense field of chemosymbiotic polychaetes at a Svalbard cold seep.

Photo: CAGE

line observations in a high-Arctic location that is likely to be influenced by warming sea temperatures, which may lead to increased seabed methane release.

KEY WORDS: Chemosynthesis - Arctic $\cdot$ Benthic ecology $\cdot$ Biodiversity $\cdot$ Siboglinidae

\section{INTRODUCTION}

Cold seeps are sites where hydrocarbons, sulfide and other reduced compounds emanate from the seabed, providing the setting to fuel chemoautotrophic production. Microbial assemblages convert these com-

() The authors 2016. Open Access under Creative Commons by Attribution Licence. Use, distribution and reproduction are unrestricted. Authors and original publication must be credited. 
pounds to organic biomass, typically through anaerobic oxidation of methane and reduction of sulfur (Boetius \& Suess 2004, Lösekann et al. 2007). Where sufficient seepage occurs, these processes can support large macrofaunal communities directly via chemosynthetic symbiosis or through trophic interactions (Levin et al. 2000, Levin 2005, Thurber et al. 2013, Zapata Hernández et al. 2014). Seafloor methane emissions may also generate the formation of carbonate outcrops, adding supplementary hard bottom substrate in otherwise soft-bottom-dominated environments (Bohrmann et al. 1998, Van Dover 2000). Cold seeps thus enhance local substrate heterogeneity on a variety of spatial scales ranging from $\mathrm{cm}$ to $\mathrm{km}$ (Bowden et al. 2013). The added habitat complexity can lead to increased biological diversity, biomass, shelter and food in these seafloor habitats (Jensen et al. 1992, Sibuet \& Olu 1998, Cordes et al. 2010). Cold seeps host complex seep-adapted faunal assemblages, in addition to conventional heterotrophic sessile organisms and vagrant megafauna, that directly or indirectly rely on the release of methane (Sibuet \& Olu 1998, Boetius \& Wenzhofer 2013, Thurber et al. 2013, Zapata Hernández et al. 2014).

Seabed emissions from vents and seeps have been discovered worldwide from shallow to hadal depths along active and passive marginal zones (Foucher et al. 2009, Vanreusel et al. 2009). Gas-saturated fluids, hydrocarbons, or gases are characteristic at vents and seeps and can be released from dissociating gas hydrates or reduced compounds stored in subseabed reservoirs (Levin 2005, Vanreusel et al. 2009). Gas hydrates are crystalline solids that enclose natural gas such as methane and are stable at high pressure and low temperatures. Dissociation of gas hydrates can strongly influence ocean chemistry (Hunter et al. 2013); free methane can escape through the water column, and may eventually reach the atmosphere (Ferré et al. 2012, Berndt et al. 2014, Sahling et al. 2014). Methane is a potent greenhouse gas (Lashof \& Ahuja 1990, MacDonald 1990) and shallow seabed emissions could potentially contribute to an increased warming of polar regions (Ruppel 2011). On the Arctic shelf of western Svalbard and the Barents Sea, gas hydrates and methane emissions have been observed in association with cold seeps, pockmarks and craters (Solheim \& Elverhøi 1993, Westbrook et al. 2009, Sahling et al. 2014). These areas are being investigated with a geophysical and geochemical approach to assess the fate of methane hydrates and gas in the context of Arctic climate change (Ferré et al. 2012, Steinle et al. 2015, Lund Myhre et al. 2016, Portnov et al. 2016).
The growing evidence of gas seepages in Svalbard indicates a widespread potential for a strong environmental driver affecting local seafloor conditions, including community structure and ecosystem function. However, seeps in high-Arctic regions are poorly explored. Further south, at the Norwegian margin, Håkon Mosby mud volcano (HMMV) was discovered in $1989\left(72^{\circ} \mathrm{N}, 14^{\circ} \mathrm{E}\right)$ at $1250 \mathrm{~m}$ water depth (Vogt et al. 1997, Lein et al. 1999). Venting of methane at HMMV occurs from gas hydrates in the sub-seabed (Vogt et al. 1997, Lein et al. 1999). Numerous biogeochemical studies have documented methane fluxes, sediment characteristics and ecological structure at the site (Gebruk et al. 2003, Niemann et al. 2006, Lösekann et al. 2007, Decker et al. 2012). Chemosynthesizing fauna have been associated with HMMV, co-occurring with heterotrophic organisms such as zoarcide fishes, pycnogonids and ophiurids, and contributing to enhanced megafaunal density and biomass compared to non-seep areas (Milkov et al. 1999, Gebruk et al. 2003).

The marine ecosystem in Svalbard is characterized by intense seasonality, with short summers and perpetual daylight, contrasting with long winters and little or no daylight and extended periods of sea ice. Within this context, seasonality in primary production, ice cover, ocean currents and the seabed sedimentary environment are strong environmental drivers of benthic communities in Svalbard and the Barents Sea (Lønne \& Gulliksen 1991, Berge et al. 2005, 2015, Carroll et al. 2008). Seabed sedimentary composition is perhaps the overriding driver of benthic community structure and function (WlodarskaKowalczuk et al. 2005, Kędra et al. 2013). Likewise, the spatial and temporal patterns of primary production, organic material export and pelagic-benthic coupling are highly variable and depth-dependent, and are key drivers of benthic diversity (Renaud et al. 2008, Wassmann \& Reigstad 2011, Søreide et al. 2013). However, benthic faunal assemblages around Svalbard have never been studied in relation to seabed methane seeps.

We investigated benthic community composition at cold seeps in 3 main regions on the Arctic shelf (<360 m depth) surrounding Svalbard $\left(75-79^{\circ} \mathrm{N}\right)$. We hypothesized that the benthic structure and biodiversity at the Svalbard cold seeps would be characterized by low diversity, high abundance and high biomass, similar to cold seeps in other parts of the world (Dubilier et al. 2008, Vanreusel et al. 2009, Cordes et al. 2010, Boetius \& Wenzhofer 2013). These Arctic seeps occur at shallower depths than most cold seep systems and may expand if ocean warming drives 
increased gas hydrate melting and sub-seabed fluid release. Our primary aim was to describe the current seep-associated communities and habitats located on the shelf of western Svalbard and the western Barents Sea. This included determining the ecological structure and diversity of macrofaunal assemblages at documented Arctic cold seeps and describing how they compare with conventional, non-seep communities.

\section{MATERIALS AND METHODS}

\section{Oceanographic setting and study area}

The Svalbard archipelago is located in the highArctic (76-81 ${ }^{\circ} \mathrm{N}$ latitude) at the northeastern North Atlantic continental shelf margin. The climate in Svalbard is relatively mild compared to other regions in the high-Arctic due to the North Atlantic Current system that transports heat from lower latitudes. The North Atlantic Current continues northward along the west coast of Spitsbergen as the West Spitsbergen Current until it diverges to the north of the archipelago and into the Arctic Ocean. West Svalbard consists of a shallower shelf where several different fjord systems terminate at the shelf margin. Along the shelf, west of the Svalbard mainland, the island Prins Karls Forland is situated in a southeastnorthwest direction (Fig. 1). Numerous locations of shallow gas seepage, containing hundreds of individual flares, have been documented on the Prins Karls Forland shelf (Westbrook et al. 2009, Sahling et al. 2014), and highly elevated concentrations of methane have been measured in the overlying water, primarily below the pycnocline (Gentz et al. 2014, Steinle et al. 2015).

Southeast of Svalbard is the Barents Sea, a marginal sea to the Arctic Ocean, characterized by shallow banks and deep troughs, originating from the last deglaciation (Dowdeswell et al. 2010), including Storfjordrenna (Storfjord Trough) and Bjørnøyrenna (Bear Island Trough), (Fig. 1). Cold Arctic water is transported southwards from the northeast Barents Sea, encountering the warmer Atlantic water where it mixes, forming the Polar Front system (Johannessen \& Foster 1978, Harris et al. 1998). The Barents Sea and western
Svalbard were largely covered by glacial ice during the last glacial period and several different postglacial features have been identified on the seafloor, including megascale glacial lineations, grounding zones, wedges and plough marks (Andreassen \& Winsborrow 2009, Patton et al. 2015). In the central part of Bjørnøyrenna $\left(74^{\circ} 54^{\prime} \mathrm{N}, 27^{\circ} 34^{\prime} \mathrm{E}\right)$, a crater field originally described by Solheim \& Elverhøi (1993) has been re-surveyed (Andreassen 2013). Numerous gas seepages and acoustic flares are associated with the craters.

\section{Benthic sampling}

Sampling occurred in June and July 2014 and May 2015 from the RV 'Helmer Hanssen' (UiT - The Arctic University of Norway). Range finding and bathymetry were conducted with multi-beam and 3D seismic surveys. Areas of active hydrocarbon seepages were chosen based on acoustic flares detected on a keelmounted, single-beam echo sounder (Simrad EK 60 frequencies 18 and 38 KHz; Fig. 2). Additionally, largescale seafloor characteristics such as craters or pockmarks were noted in the cruise log. Vertical conductivity, temperature, depth (SBE 9 plus sensor) profiles of seawater hydrography were taken prior to benthic sampling. Quantitative sampling was carried out in 3 main regions: western Svalbard (WS; i.e. Prins Karls Forland shelf, PKF), Storfjordrenna (SR) and Bjørnøyrenna (BR; Fig. 1), covering in total 10 stations.

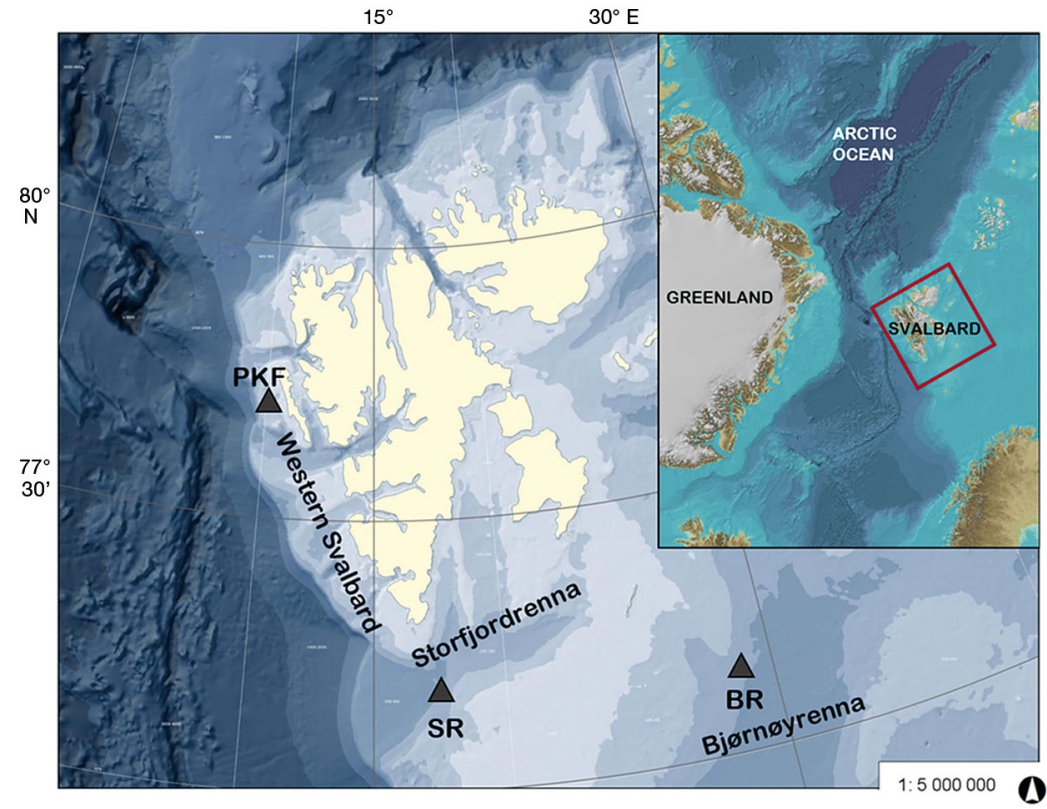

Fig. 1. Study region. PKF: Prins Karls Forland, SR: Storfjordrenna, and BR: Bjørnøyrenna (Jakobsson et al. 2012, Norsk Polarinstitutt, npolar.no) 


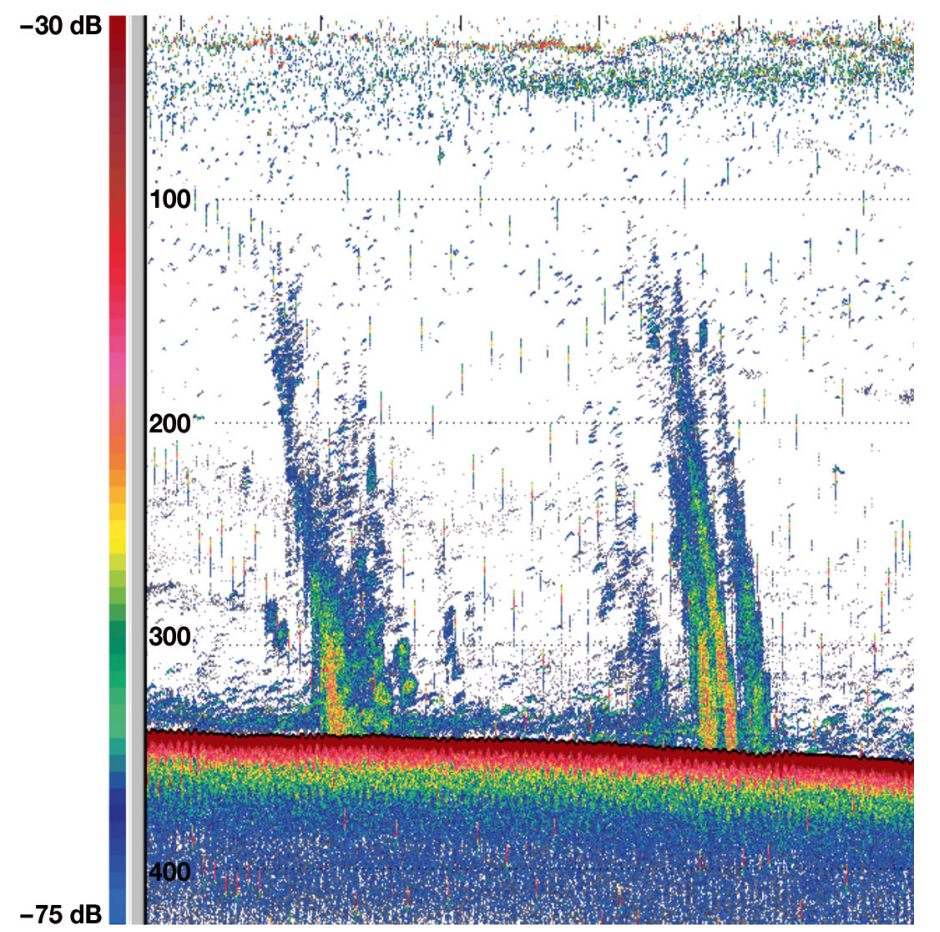

Fig. 2. Acoustic flares from Storfjordrenna, recorded with a Simrad EK 60 single-beam echo sounder. Vertical scale represents water depth $(\mathrm{m})$

In each region, we selected stations in active seep areas where we identified and targeted strong flare activity on the echo sounder. These stations were sampled along with control stations ranging from 1 to $41.5 \mathrm{~km}$ outside the zone of flare activity (for coordinates, depth and oceanographic parameters see Table 1). Each station was sampled with 5 quantitative replicate van Veen grab samples $\left(0.1 \mathrm{~m}^{2}\right)$ for fauna and an additional sixth qualitative replicate was sampled for sediment characteristics. Given the capabilities of the ship and no visual guidance on the seabed, our replicate samples within a station were on the order of $10 \mathrm{~s}$ of meters apart. Sampling was targeted at the center of the flare base as observed on the echo sounder, with variable success among replicates of hitting the exact center of the seep (Fig. 3). Prior to processing a grab sample, each grab was visually inspected from the inspection port to ensure sample integrity, (i.e. closed jaws, filled and undisturbed surface layer). Furthermore, observations were made about indicators of seep activity including black mud, $\mathrm{H}_{2} \mathrm{~S}$ odor or authigenic carbonates. Quantitative samples were treated in accordance with ISO 16665:2014 fieldwork protocols and sieved on-board with a mesh size of $500 \mu \mathrm{m}$. Material retained on the sieve was fixed in formaldehyde $(4 \%)$ and mixed with rose bengal for staining living tissues, and the solution was buffered with borax (sodium tetra-borate decahydrate). Samples were sorted and identified in the biological laboratory of Akvaplan-niva (Tromsø, Norway) and stored in $80 \%$ ethanol. Organisms were separated into main phyletic groups and identified to the lowest possible taxonomic level. Each individual was counted and weighed (aggregated wet weight in phyletic groups). Planktonic taxa that are not benthic were excluded from analysis, as were Foraminifera and $\mathrm{Ne}$ matoda, as these taxa are not properly retained on a $500 \mu \mathrm{m}$ mesh size. Colonial taxa such as Porifera, Hydrozoa and Bryozoa were excluded in the total abundance, but poriferans, hydrozoans and foliose bryozoans were included in the overall biomass for phyletic groups. Phyletic groups were separated into Crustacea, Echinodermata, Mollusca, Polychaeta and 'diverse.' The group 'diverse' included Brachiopoda, Chordata, Cnidaria, Hemicordata, Nemertea, Oligochaeta, Platyhelminthes, Priapulida and Sipuncula for abundances and, in addition, Porifera, Hydrozoa and Bryozoa for biomass.

Table 1. Detailed information on sampling stations in western Svalbard and the Barents Sea

\begin{tabular}{|lccccccc|}
\hline Area & Station & $\begin{array}{c}\text { Date } \\
\text { sampled }\end{array}$ & $\begin{array}{c}\text { Lat. } \\
{ }^{\circ} \mathrm{N}\end{array}$ & $\begin{array}{c}\text { Lon. } \\
{ }^{\circ} \mathrm{E}\end{array}$ & $\begin{array}{c}\text { Depth } \\
(\mathrm{m})\end{array}$ & $\begin{array}{c}\text { Salinity } \\
(\mathrm{psu})\end{array}$ & $\begin{array}{c}\text { Temp. } \\
\text { bottom }\left({ }^{\circ} \mathrm{C}\right)\end{array}$ \\
\hline Western shelf (control) & V 12 & 20.06 .2014 & $78^{\circ} 59.5^{\prime}$ & $09^{\circ} 29.5^{\prime}$ & 212 & 35.1 & 2.2 \\
Western shelf (seep) & PKF 1 & 21.06 .2014 & $78^{\circ} 39.3^{\prime}$ & $09^{\circ} 26.2^{\prime}$ & 248 & 35.1 & 3.0 \\
Western shallow shelf (control) & PKF 853 & 17.05 .2015 & $78^{\circ} 34.1^{\prime}$ & $10^{\circ} 07.3^{\prime}$ & 88 & 35.1 & 1.4 \\
Western shallow shelf (seep) & PKF 5 & 27.06 .2014 & $78^{\circ} 33.6^{\prime}$ & $10^{\circ} 09.0^{\prime}$ & 86 & 35.1 & 3.8 \\
Storfjordrenna (seep) & SR 1 & 09.07 .2014 & $75^{\circ} 50.48^{\prime}$ & $16^{\circ} 35.55^{\prime}$ & 353 & 35.05 & 2.4 \\
Storfjordrenna (control) & SR 2 & 10.07 .2014 & $75^{\circ} 52.47^{\prime}$ & $16^{\circ} 38.56^{\prime}$ & 350 & 35.06 & 2.4 \\
Bjørnøyrenna crater 1 (seep) & BR 1 & 15.07 .2014 & $74^{\circ} 57.05^{\prime}$ & $27^{\circ} 35.95^{\prime}$ & 344 & 35.10 & 1.6 \\
Bjørnøyrenna crater 2 (seep) & BR 2 & 16.07 .2014 & $74^{\circ} 53.94^{\prime}$ & $27^{\circ} 31.78^{\prime}$ & 357 & 35.08 & 1.7 \\
Bjørnøyrenna 3 field (seep) & BR 3 & 16.07 .2014 & $75^{\circ} 54.09^{\prime}$ & $27^{\circ} 33.39^{\prime}$ & 337 & 35.10 & 1.7 \\
Bjørnøyrenna shelf (control) & PFT 16 & 18.07 .2014 & $75^{\circ} 08.97^{\prime}$ & $28^{\circ} 35.50^{\prime}$ & 334 & 35.10 & 1.4 \\
\hline
\end{tabular}




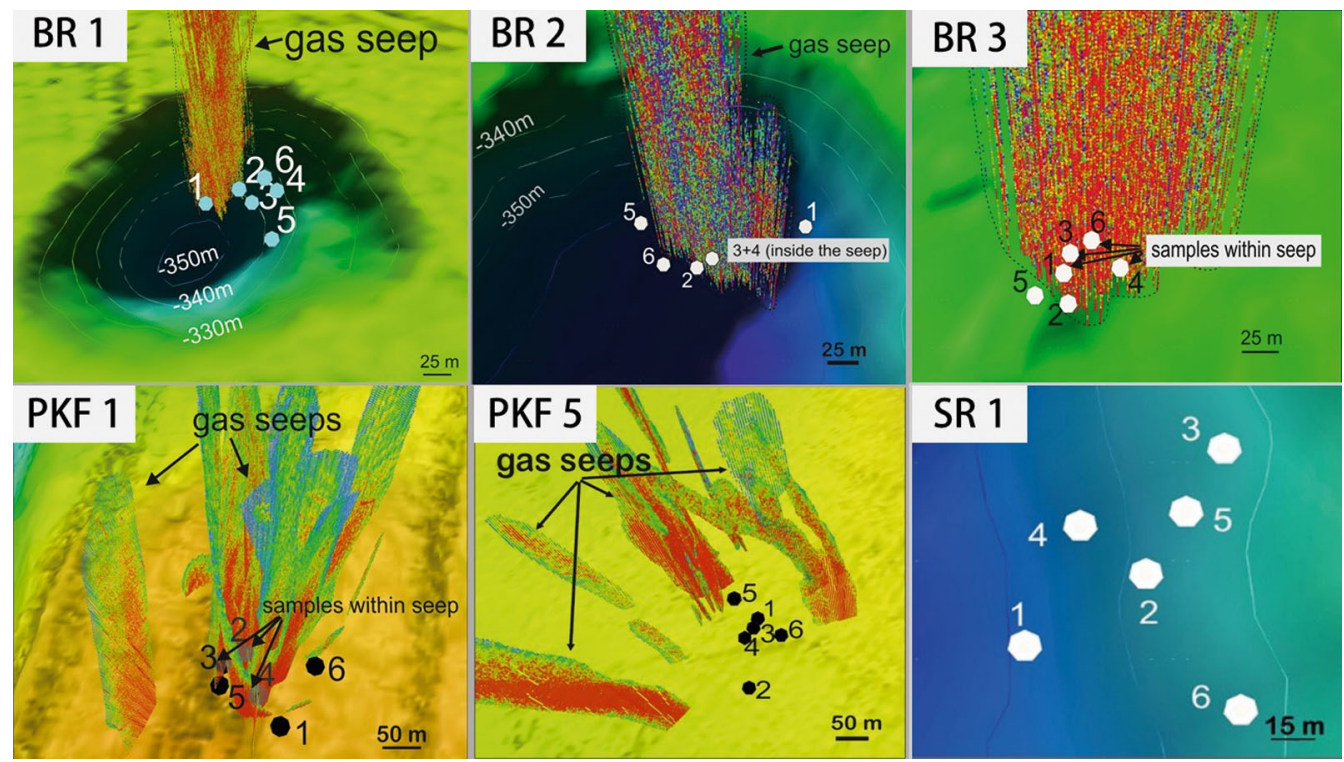

Fig. 3. Detailed illustrations of individual a priori seep stations based on acoustic flares detected by echo sounder on board the vessel. Points representing individual replicates are mapped according to the surface position of the vessel when the grab hit the sea floor. Gas flares are projected from repeated seismic lines over the target area. No acoustic flare data were available from station SR 1. See Tables 1 \& 2 for station information

\section{Sediment and benthic pigment analysis}

Sediment grain size and total organic carbon (TOC) were determined by subsampling grab samples (minimum $50 \mathrm{~g}$ ) from a qualitative grab sample at each station (see Table 2). Grain size was determined in accordance with Bale \& Kenny (2005). The TOC samples were analyzed with a Shimadzu SSM TOC 5000 and Elementar Vario TOC Cube.

Porosity from sediment samples was determined by using a wet-dry method where pre-weighed vials of known volume were filled properly with sediment, re-weighed, and later dried at $60^{\circ} \mathrm{C}$ until all water evaporated (Zaborska et al. 2008). Density was obtained using the basis from the wet weight of sediment and water combined. Porosity values from station BR 3 were derived from samples collected during 2015. For the shallow PKF stations (PKF 5 and PKF 853), porosity values were determined using a nearby station with similar depth and sediment characteristics.

Sediment pigment concentrations (chlorophyll a [chl a] and phaeopigments) were analyzed by fluorometry at 9 of the 10 stations (see Table 2) in accordance with Holm-Hansen et al. (1965). Sediment was obtained either by slicing push cores from a qualitative grab sample (5 $\mathrm{cm}$ diameter) in $1 \mathrm{~cm}$ intervals or by using a surface $(0-2 \mathrm{~cm})$ layer of sediment from grab samples. Chlorophyll and benthic pigment samples were extracted with acetone and measured for fluorescence in a Turner Designs Model 10 AU fluorometer before and after acidification with hydrogen chloride $(\mathrm{HCl})$. The measured concentration was corrected for sediment porosity.

\section{Statistical analysis}

Faunal abundances were analyzed for diversity indices including species richness $(S)$, evenness $\left(J^{\prime}\right)$ and Shannon-Wiener diversity $\left(H^{\prime} \log _{\mathrm{e}}\right)$ using Primer 6 (Clarke \& Gorley 2006). The non-metric multidimensional scaling plot (nMDS) was based on a Bray-Curtis matrix for similarity assembled on taxon abundances from standardized and transformed (single square-root) data. Single square-root transformation and standardization were carried out to balance the community effect of the highly abundant and rarer taxa and to control the high variability between replicate samples. A 2-way crossed ANOSIM (Clarke 1993) was performed at the replicate level to test whether differences in community structure based on the Bray-Curtis similarity matrix were significant for region (BR, SR and WS) and impact (seep or control).

Two-factor ANOVA was used to test differences in community structure by the 2 factors 'region' and 'impact' (i.e. control vs. seep). Analysis for 2 -factor ANOVA (type III, unbalanced design) was performed using SigmaPlot ${ }^{\mathrm{TM}}$ v12.5, after testing the conformity of the datasets to the assumptions of ANOVA (nor- 
mality of distributions and homogeneity of variances). We first tested for community differences at the station level in order to examine broad-scale differences among region and seep influences; all replicates at a given station were coded as a seep or control as selected a priori at the time of sampling, regardless of the location of the individual replicate sample in relation to the flare (Fig. 3). All pairwise multiple comparison procedures were tested using the Holm-Sidak test with an overall significance level of $p \leq 0.05$. Following this station-level analysis, individual replicates at seeps were separated based on additional criteria and characteristics of the sample, including presence of black mud, sulfide odor, authigenic carbonate crusts and presence of chemosymbiotic fauna. This outcome was supported by the results of the Bray-Curtis similarity analysis nMDS plot. This process resulted in a refined selection of 4 clearly methane seep-influenced (MSI) replicates, which were compared to control replicates from the Barents Sea region using 1-factor ANOVA (non-parametric Kruskal-Wallis test) with pairwise multiple comparison (Dunn's Method).

Pearson's correlation coefficients (r) were calculated to determine individual pairwise relationships between environmental variables and univariate faunal community data. The influence of environmental variables was examined through multivariate analysis using the statistical computing software R. Canonical correspondence analysis (CCA) was used to test the ordination of stations in relation to standardized environmental variables. We tested water depth, bottom water temperature, salinity, sediment characteristics including grain size fraction $(<63 \mu \mathrm{m})$, total organic carbon $(\%)$, porosity and benthic pigments (total concentration of $\mathrm{chl} a$ and phaeopigments) against total faunal abundance. Furthermore, total station biomass and the categorical value of 'seep' were added to the plot as explanatory variables.

\section{RESULTS}

\section{Faunal communities}

In 50 replicates among 10 stations, we identified 35559 individuals in total, belonging to 400 taxa and 12 phyla. The phylum with the highest abundance was Annelida (class Polychaeta) with 22420 individuals distributed among 224 taxa and representing $63.1 \%$ of the total faunal sample. The second largest group was Mollusca, divided among 74 taxa, corresponding to 7008 individuals and representing $19.7 \%$ of the total faunal sample. Mean \pm SD organism density was $7112 \pm 2203$ ind. $\mathrm{m}^{-2}$ per station but with a large range among stations (4382 to 12050 ind. $\mathrm{m}^{-2}$ ) (Table 2). Both lowest and highest abundance per station were located in BR, at sites BR 2 and BR 3, respectively (Fig. 4 a, Table 2). Mean $S$ was $141 \pm 23$ taxa per station, with a range from 114 at BR 2 to 184 at PKF 1 (Table 2). Total biomass aggregated by station was dominated by polychaetes, representing $614.8 \mathrm{~g}$ wet weight (ww) and contributing to $38.3 \%$ of total biomass. Mollusks and echinoderms had a total weight of 428.2 and $401.0 \mathrm{~g} \mathrm{ww}$, comprising 26.7 and $25.0 \%$, respectively, of total sample weight. The highest biomass per station was $321.0 \mathrm{~g} \mathrm{ww} \mathrm{m}^{-2}$, at shallow PKF 5, followed by seep station SR 1 with $245.7 \mathrm{~g} \mathrm{ww} \mathrm{m}^{-2}$; the lowest biomass $\left(54.4 \mathrm{~g} \mathrm{ww} \mathrm{m}^{-2}\right)$ was found at the control station in Bjørnøyrenna, PFT 16 (Fig. 4b).

Table 2. Summary of faunal and environmental characteristics by station, including pelite fraction $(<63 \mu \mathrm{m})$; chl a: chlorophyll a concentration per volume of sediment; and concentration of phaeopigments per volume of sediment. TOC: total organic carbon, ns: no samples. See Table 1 for station information

\begin{tabular}{|c|c|c|c|c|c|c|c|c|c|c|c|c|}
\hline Station & $\begin{array}{l}\text { Depth } \\
\text { (m) }\end{array}$ & $\begin{array}{c}\text { Species } \\
\text { richness } \\
\quad(S)\end{array}$ & $\begin{array}{c}\text { Taxon } \\
\text { density } \\
\text { (ind. } \mathrm{m}^{-2} \text { ) }\end{array}$ & $\begin{array}{c}\text { Species } \\
\text { evenness } \\
\left(J^{\prime}\right)\end{array}$ & $\begin{array}{c}\text { Species } \\
\text { diversity } \\
\left(H^{\prime}\right)\end{array}$ & 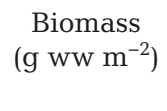 & $\begin{array}{l}\text { Porosity } \\
0-2 \mathrm{~cm}\end{array}$ & $\begin{array}{c}\text { Pelite } \\
\text { fraction } \\
(\%)\end{array}$ & $\begin{array}{l}\text { TOC } \\
(\%)\end{array}$ & $\begin{array}{c}\text { Benthic } \\
\text { chl } a \\
\left(\mathrm{mg} \mathrm{m}^{-3}\right)\end{array}$ & $\begin{array}{l}\text { Benthic phaeo- } \\
\text { pigments } \\
\left(\mathrm{mg} \mathrm{m}^{-3}\right)\end{array}$ & $\begin{array}{c}\text { Ratio chl a: } \\
\text { phaeo- } \\
\text { pigments }\end{array}$ \\
\hline V 12 & 212 & 161 & 5720 & 0.79 & 4.0 & 106.8 & 0.36 & 30.2 & 1.16 & 3878.2 & 12172.9 & 0.32 \\
\hline PKF 1 & 248 & 184 & 7058 & 0.78 & 4.0 & 136.5 & 0.38 & 19.2 & 0.51 & ns & ns & $\mathrm{ns}$ \\
\hline PKF 853 & 88 & 150 & 8450 & 0.69 & 3.5 & 241.2 & 0.19 & 17.5 & 0.79 & 3399.1 & 11397.0 & 0.30 \\
\hline PKF 5 & 86 & 163 & 8144 & 0.74 & 3.8 & 321.0 & 0.19 & 33.7 & 0.82 & 3584.6 & 14382.7 & 0.25 \\
\hline SR 1 & 353 & 125 & 7684 & 0.69 & 3.3 & 245.7 & 0.66 & 88.5 & 1.55 & 1933.1 & 8056.5 & 0.24 \\
\hline SR 2 & 350 & 118 & 5564 & 0.69 & 3.3 & 64.8 & 0.68 & 84.9 & 1.40 & 2141.6 & 8966.3 & 0.24 \\
\hline BR 1 & 344 & 130 & 7022 & 0.62 & 3.0 & 146.1 & 0.71 & 74.2 & 1.80 & 1873.5 & 7401.9 & 0.25 \\
\hline BR 2 & 357 & 114 & 4382 & 0.59 & 2.8 & 160.0 & 0.71 & 72.0 & 1.54 & 2744.3 & 9665.0 & 0.28 \\
\hline BR 3 & 337 & 128 & 12050 & 0.40 & 1.9 & 130.3 & 0.52 & 72.3 & 1.41 & $1290.6^{\mathrm{a}}$ & $4914.5^{\mathrm{a}}$ & 0.26 \\
\hline PFT 16 & 334 & 120 & 5040 & 0.63 & 3.0 & 54.5 & 0.62 & 86.0 & 1.87 & 2357.9 & 7115.1 & 0.33 \\
\hline
\end{tabular}




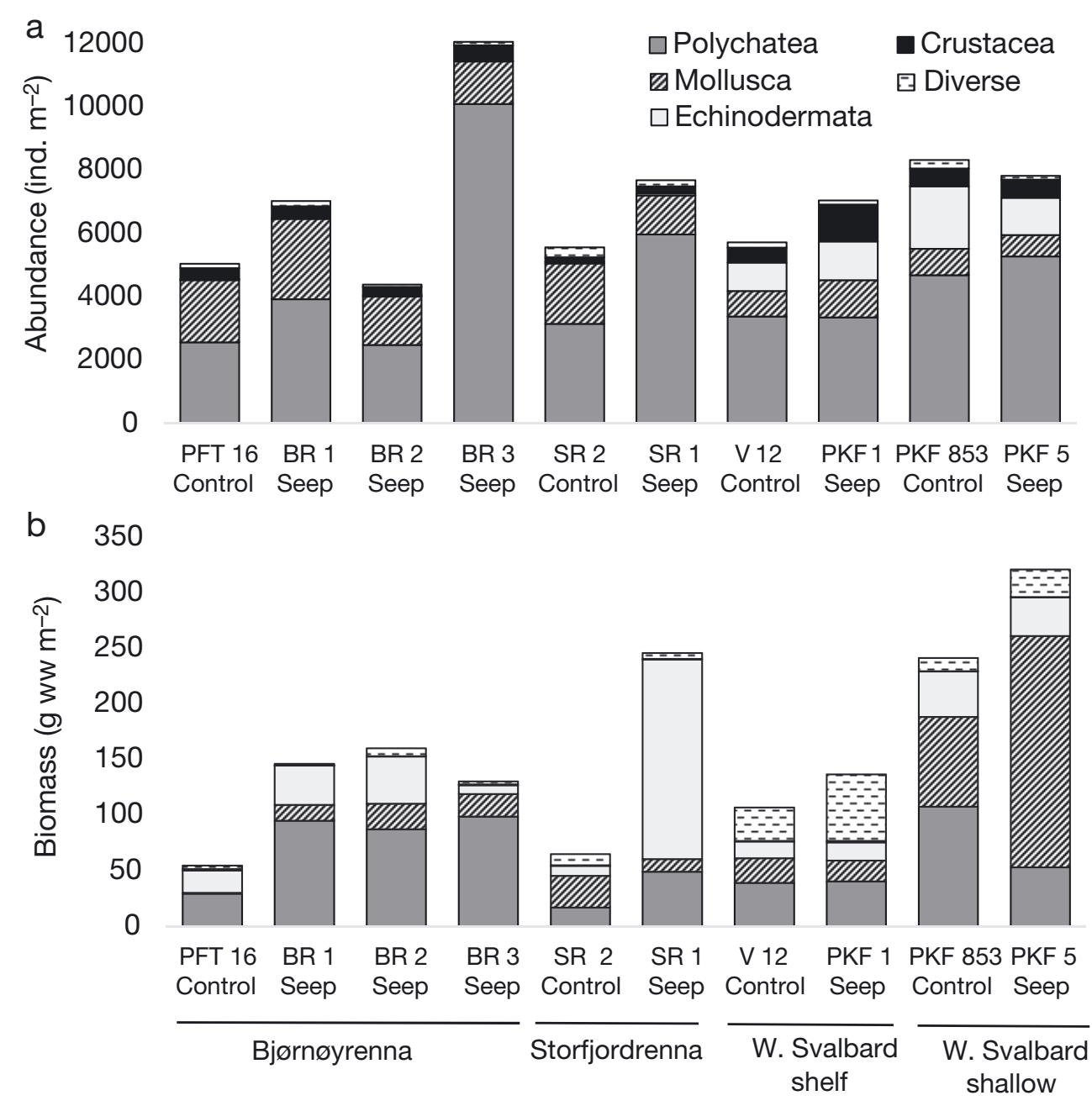

Fig. 4. (a) Faunal abundances (ind. $\mathrm{m}^{-2}$ ) and (b) biomass ( $\mathrm{g} w \mathrm{w} \mathrm{m}^{-2}$ ) aggregated by station

\section{Dominant taxa}

Polychaeta were the most abundant faunal group; 8 of the top 10 most abundant taxa were polychaetes (Table 3). The most abundant taxon overall, however, was a bivalve in the family Thyasiridae, Mendicula cf. pygmaea (Verrill \& Bush, 1898), representing $13.2 \%$ of the total sample and present in 47 of 50 faunal replicates. The second most abundant taxon were chemosymbiotic polychaetes in the family Siboglinidae, which contributed $12.5 \%$ of the total sample despite occurring only at seep locations (18 out of 50 replicates, Table 3). Brittlestars (unidentified Ophiuridea) was the third most abundant taxon $(5.7 \%)$. In total, the 10 most abundant taxa comprised slightly over $50 \%$ of the total sample, with the top 3 species representing approximately $30 \%$. In a priori seep stations only, siboglinid polychaetes were the dom- inant taxon, comprising almost $20 \%$ of the total sample, followed by $M$. cf. pygmaea (13.2\%) and the polychaete Spiochaetopterus typicus M. Sars, $1856(6.9 \%)$. No Siboglinidae were present in the controls; here, $M$. cf. pygmaea was the predominate species, contributing to $13.2 \%$ of the total number of individuals. Furthermore, there was a high abundance of brittlestars (unidentified Ophiuroida) in the controls $(9.8 \%)$, primarily represented by juveniles from the stations located in WS, followed by the polychaete Levinsenia gracilis (Tauber, 1879), comprising $4.4 \%$ of the total abundance. At seeps, the top 10 most abundant taxa represented $55.4 \%$ of the total sample compared to $49.1 \%$ at the control stations. The 3 most common organisms collected at seeps comprised nearly $40 \%$ of all individuals. At control stations, this number was substantially lower, where the top 3 taxa represented $27.4 \%$ of the total sample. 
Table 3. Percentage dominance of the 10 most common species (in bold) based on faunal density at all stations (total) and between a priori grouped cold seeps and control stations. Faunal group abbreviations are given in parentheses; Pol: Polychaeta; Biv: Bivalvia; E: Echinodermata. The total number of stations for each category is shown in parentheses in the top row

\begin{tabular}{|lccc|}
\hline Taxon & $\begin{array}{c}\text { Total } \\
(10)\end{array}$ & $\begin{array}{c}\text { Seeps } \\
(6)\end{array}$ & $\begin{array}{c}\text { Controls } \\
(4)\end{array}$ \\
\hline Mendicula cf. pygmaea (Biv) & $\mathbf{1 3 . 2}$ & $\mathbf{1 3 . 2}$ & $\mathbf{1 3 . 2}$ \\
Siboglinidae unid. (Pol) & $\mathbf{1 2 . 5}$ & $\mathbf{1 9 . 2}$ & 0.0 \\
Ophiuroidea unid. (E) & $\mathbf{5 . 7}$ & $\mathbf{3 . 5}$ & $\mathbf{9 . 8}$ \\
Spiochaetopterus typicus (Pol) & $\mathbf{5 . 7}$ & $\mathbf{6 . 9}$ & 2.3 \\
Levinsenia gracilis (Pol) & $\mathbf{3 . 8}$ & $\mathbf{3 . 4}$ & $\mathbf{4 . 4}$ \\
Maldane sarsi (Pol) & $\mathbf{2 . 5}$ & 0.6 & $\mathbf{4 . 1}$ \\
Galathowenia oculata (Pol) & $\mathbf{2 . 4}$ & $\mathbf{2}$ & $\mathbf{3 . 3}$ \\
Heteromastus filiformis (Pol) & $\mathbf{2 . 1}$ & $\mathbf{1 . 8}$ & $\mathbf{2 . 7}$ \\
Pholoe assimilis (Pol) & $\mathbf{1 . 9}$ & 1.5 & $\mathbf{2 . 6}$ \\
Prionospio cirrifera (Pol) & $\mathbf{1 . 9}$ & 1.1 & $\mathbf{3 . 4}$ \\
Nothria hyperborea (Pol) & 1.8 & 1 & $\mathbf{3 . 3}$ \\
Spiophanes kroeyeri (Pol) & 1.7 & $\mathbf{1 . 7}$ & 1.5 \\
Scoloplos sp. (Pol) & 1.6 & $\mathbf{1 . 7}$ & 1.4 \\
Cossura longocirrata (Pol) & 1.5 & $\mathbf{2}$ & 0.7 \\
Lumbrineris mixochaeta (Pol) & 1.3 & 0.8 & $\mathbf{2 . 3}$ \\
Total sum (\%) of top 10 taxa & 51.7 & 55.4 & 49.1 \\
\hline
\end{tabular}

\section{Environmental variables}

Pearson's correlation coefficient results from selected environmental variables and faunal parameters showed a significant $(\mathrm{p}<0.05)$ negative correlation between $S$ and water depth (r $=-0.71$ ) along with the sediment characteristics TOC $(\mathrm{r}=-0.73)$ and grain size $(<63 \mu \mathrm{m} ; \mathrm{r}=-0.88$; Table 4$)$. Faunal diversity, represented by $H^{\prime}$ and $J^{\prime}$, had the strongest positive significant correlation to sedimentary pigments (chl a + phaeopigments; $r=0.78$ and $r=0.76$, respectively). Biomass showed a weak negative correlation to water depth $(\mathrm{r}=-0.62 ; \mathrm{p}<0.10)$, but biomass did not have any correlation to other tested variables. We found no significant correlation between faunal abundance and any of the selected variables.

CCA, with multivariate constrained ordination, was used to identify the influences of environmental variables at each station to assess the total station biomass and faunal abundance. Station taxon abundances and biomass were plotted along environmental variables: depth, TOC, grain size fraction, temperature, benthic pigments, porosity, salinity and the categorical value of seep (Fig. 5, Table 2). Isolines are based on the abundance of Siboglinidae and the bivalve $M$. cf. pygmaea, the 2 most dominant taxa in this investigation. There is a clear separation of WS stations and the stations in the Barents Sea (first axis, CCA1; Fig. 5) in the ordination of taxa and variables. WS stations were characterized by high temperatures, high concentration of sedimentary pigments and shallow depths. Control stations from the Barents Sea and the stations BR 1 and BR 2 are defined by depth and sedimentary characteristics of porosity, grain size and TOC, together with high densities of the bivalve $M$. cf. pygmaea. Stations SR 1 and BR 3 are ordinated by the categorical value 'seep' and follow the isolines for high densities of Siboglinidae polychaetes.

\section{Community patterns}

The 2-way crossed ANOSIM (based on the BrayCurtis matrix) indicated a significant difference in community structure for the factor 'region' (global $\mathrm{R}=0.797, \mathrm{p}<0.001$ ); however, no significant difference was seen for 'impact' (global $\mathrm{R}=0.168, \mathrm{p}=$ 0.064). Further, a 2-factor ANOVA tested the factors 'region' (BR, SR, WS) and 'impact' of seep (seep vs. control, selected a priori). We found no significant differences in faunal abundances among 'regions' or with respect to 'impact' ( $\mathrm{p}>0.05$; Table 5a). $S$ and $H^{\prime}$ both showed significant differences among regions (Table 5a), where WS had higher $S$ and $H^{\prime}$ compared to BR and SR (Table 5b). The factors 'region' and 'impact' showed a significant interaction for $S$ ( $\mathrm{p}<$ 0.05, Table 5a).

Pairwise comparisons for $S$ and $H^{\prime}$ from the a priori selected seep stations in the 3 regions indicate that WS (PKF) had significantly higher $(p<0.01)$ values than both Barents Sea locations (BR and SR), whereas there was no difference between the locations within the Barents Sea (Table 6). There was a similar spatial pattern when comparing the controls;

Table 4. Pearson's correlation coefficients (r-values) relating selected environmental variables to benthic community structure: abundance, species richness $(S)$, biomass, diversity $\left(H^{\prime}\right)$, and evenness $\left(J^{\prime}\right)$. Significant relationships are shown in bold $;{ }^{*} \mathrm{p}<0.05,{ }^{* *} \mathrm{p}<0.01,{ }^{* * *} \mathrm{p}<0.001$. TOC: total organic carbon

\begin{tabular}{|lccccc|}
\hline & Abundance & $S$ & Biomass & $H^{\prime}$ & $J^{\prime}$ \\
\hline $\begin{array}{l}\text { Temperature } \\
\text { (bottom water) }\end{array}$ & 0.07 & 0.60 & 0.48 & -0.44 & 0.53 \\
Depth & -0.22 & $\mathbf{- 0 . 7 1 *}$ & -0.62 & -0.56 & -0.49 \\
Benthic pigments & -0.28 & 0.62 & 0.50 & $\mathbf{0 . 7 8}^{* *}$ & $\mathbf{0 . 7 6}^{*}$ \\
TOC & 0.28 & $\mathbf{- 0 . 7 3}$ & -0.47 & -0.51 & -0.43 \\
Grain size $(\%<0.63 \mu \mathrm{m})$ & -0.17 & $\mathbf{- 0 . 8 8 * *}$ & -0.39 & -0.62 & -0.52 \\
\hline
\end{tabular}


Fig. 5. Canonical correspondence analysis (CCA) based on station abundances of taxa ordinated with standardized environmental variables: temperature, depth, salinity, pelite fraction $(<0.63 \mu \mathrm{m})$, total organic carbon (TOC $; \%)$, porosity, and the categorical variable 'seep' in combination with aggregated station biomass. Abundances of the 2 most common taxa are presented as isolines (solid black lines: Mendicula cf. pygmaea [bivalve]; dashed grey lines: Siboglinidae [polychaetes]). Arrows along the ordination of taxon and station scores illustrate the supplemental variables; arrow length represents the importance of the variable to community structure. The direction of the arrows in relation to the taxa and stations illustrates the impact of the variable for those particular stations or taxa, and the angle between the different arrows represents the relationship between variables. See Tables 1 \& 2 for station information

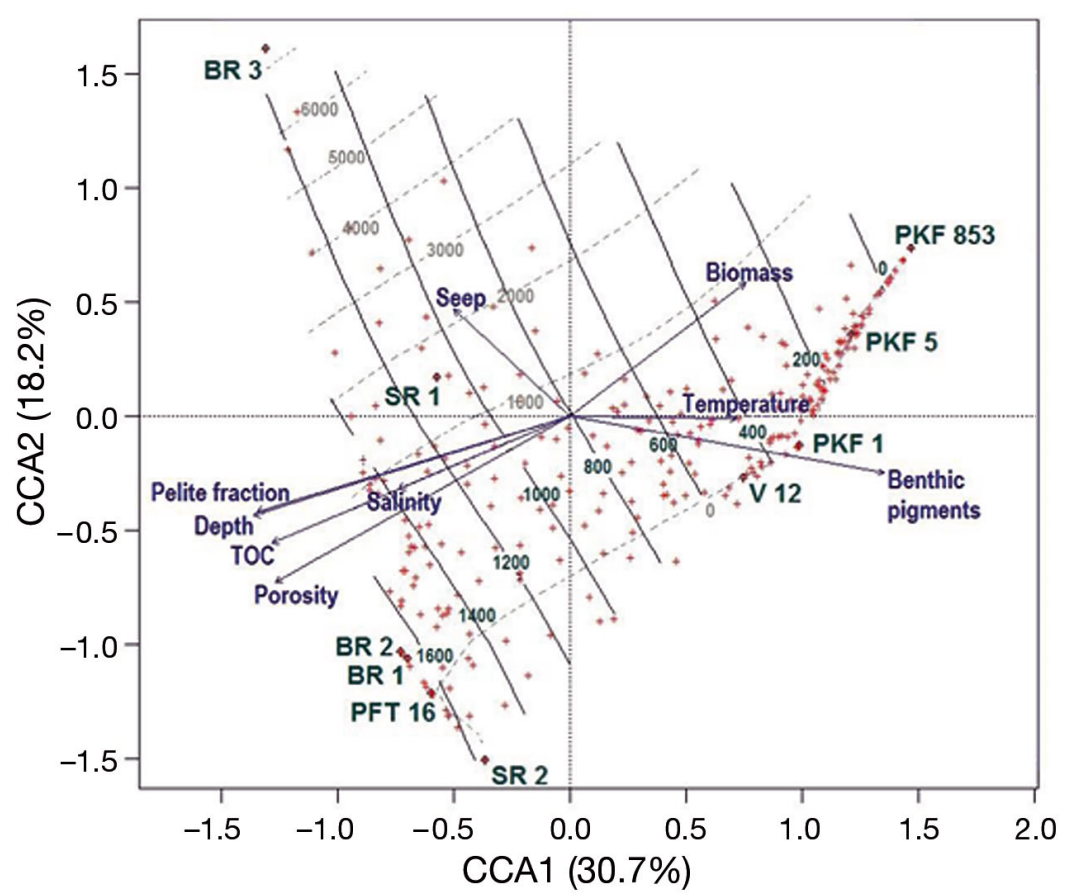

significant differences were seen between WS stations and those in the Barents Sea, with one exception for $H^{\prime}$ where WS was different only from $B R$, and not SR controls.

Within the WS region only, the 2 seep stations (PKF 1 and PKF 5) had significantly higher $S$ (mean \pm SE: $99 \pm 3$ taxa $0.1 \mathrm{~m}^{-2}$ ) compared to the 2 controls $(85 \pm 3$ taxa 0.1 $\left.\mathrm{m}^{-2} ; \mathrm{p}<0.05\right)$. However, no differences were evident in overall abundances or $H^{\prime}$. In the Barents Sea (within SR and BR), there were no differences between seeps and controls for any of the tested faunal parameters.

For biomass, the 2-factor ANOVA testing the difference between 'region' and 'impact' showed no significant differences between regions ( $p>0.05$, Table 5a,b). Biomass did vary with seep impact, with a significantly higher biomass $(\mathrm{p}<0.05)$ at seep stations $\left(20.7 \pm 2.4 \mathrm{~g}\right.$ ww $\left.0.1 \mathrm{~m}^{-2}\right)$ compared to controls $(9.8 \pm 3.8 \mathrm{~g} \mathrm{ww}$ $0.1 \mathrm{~m}^{-2}$; Table 5a,b).

Multivariate analysis of community structure by nMDS showed
Table 5. (a) Results of 2-way ANOVA for faunal community parameters: species richness, abundance $\left(0.1 \mathrm{~m}^{-2}\right)$, diversity $\left(H^{\prime}, \log _{\mathrm{e}}\right)$, and biomass $\left(\mathrm{g}\right.$ ww $\left.0.1 \mathrm{~m}^{-2}\right)$ among the factors 'region' and 'impact' (seep and control). Significant differences are shown in bold $;{ }^{*} \mathrm{p}<0.05,{ }^{* *} \mathrm{p}<0.01,{ }^{* * *} \mathrm{p}<0.001$. (b) Mean $( \pm \mathrm{SE})$ faunal parameters for replicates. BR: Bjørnøyrenna, SR: Storfjordrenna, WS: western Svalbard

\begin{tabular}{|c|c|c|c|c|c|}
\hline (a) & df & MS & $F$ & $\mathrm{p}$ & \\
\hline \multicolumn{6}{|l|}{ Species richness } \\
\hline Region & 2 & 4430.48 & 48.78 & \multicolumn{2}{|c|}{$<0.001^{* * *}$} \\
\hline Impact & 1 & 157.95 & 1.74 & \multicolumn{2}{|l|}{0.194} \\
\hline Region $\times$ Impact & 2 & 332.68 & 3.66 & \multicolumn{2}{|c|}{$0.034^{*}$} \\
\hline Residuals & 44 & 90.83 & & & \\
\hline \multicolumn{6}{|l|}{ Abundance } \\
\hline Region & 2 & 40061.25 & 0.25 & \multicolumn{2}{|l|}{0.781} \\
\hline Impact & 1 & 337958.59 & 2.10 & \multicolumn{2}{|l|}{0.154} \\
\hline Region $\times$ Impact & 2 & 59847.24 & 0.37 & \multicolumn{2}{|l|}{0.696} \\
\hline Residuals & 44 & 160861.13 & & & \\
\hline \multicolumn{6}{|l|}{ Diversity } \\
\hline Region & 2 & 3.43 & 19.55 & \multicolumn{2}{|c|}{$<0.001^{* * *}$} \\
\hline Impact & 1 & 0.17 & 0.98 & \multicolumn{2}{|l|}{0.328} \\
\hline Region $\times$ Impact & 2 & 0.336 & 1.92 & \multicolumn{2}{|l|}{0.159} \\
\hline Residuals & 44 & 0.175 & & & \\
\hline \multicolumn{6}{|l|}{ Biomass } \\
\hline Region & 2 & 441.21 & 3.05 & \multicolumn{2}{|l|}{0.057} \\
\hline Impact & 1 & 1230.57 & 8.51 & \multicolumn{2}{|c|}{$0.006^{* *}$} \\
\hline Region $\times$ Impact & 2 & 133.31 & 0.92 & \multicolumn{2}{|l|}{0.405} \\
\hline Residuals & 44 & 144.54 & & & \\
\hline \multirow{2}{*}{$\begin{array}{l}\text { (b) } \\
\text { Faunal parameter }\end{array}$} & \multicolumn{3}{|c|}{ - Region- } & \multicolumn{2}{|c|}{ Impact } \\
\hline & $\mathrm{BR}$ & SR & WS & Seep & Control \\
\hline Species richness & $63(3)$ & $66(3)$ & $92(3)$ & $75(2)$ & $72(2)$ \\
\hline Abundance & $643(103)$ & $662(127)$ & $734(90)$ & $770(81)$ & $590(95)$ \\
\hline Diversity & $2.72(0.11)$ & $3.02(0.13)$ & $3.59(0.01)$ & $3.05(0.09)$ & $3.17(0.10)$ \\
\hline Biomass & $10.0(3.1)$ & $15.5(3.8)$ & $20.1(2.7)$ & $20.7(2.4)$ & $9.8(3.8)$ \\
\hline
\end{tabular}


2 main clusters of the replicate samples on a regional scale, with samples from the WS stations separated from the Barents Sea stations by $27 \%$ similarity (Fig. 6). At WS, replicates were well clustered within stations, and there was also a separation between the shallower (85-88 m) and deeper (212-248 m) replicates at $45 \%$ similarity (not indicated on Fig. 6). In the Barents Sea, stations were clustered together in a more diffuse pattern separating mainly SR from BR replicates. A third cluster of 4 samples occurred at $39 \%$ similarity, diverging from both WS and the rest of the Barents Sea samples. This cluster is represented by 2 replicates each from the BR flare field station (BR 3) and the SR cold seep (SR 1). These 4 replicates showed clear evidence of seepage, with a strong odor of sulfide $\left(\mathrm{H}_{2} \mathrm{~S}\right)$, darkcolored mud, carbonate crust in the sediment and high densities of seepassociated fauna (Fig. 7). Siboglinid tubeworms were recorded in densities of over 1500 ind. $\mathrm{m}^{-2}$ at SR and 7272 ind. $\mathrm{m}^{-2}$ at BR. The 4 replicates, all from the Barents Sea and demonstrating strong MSI (Figs. 6 \& 7), were compared in a single-factor ANOVA against controls in the Barents Sea (SR and BR controls) for faunal parameters. The selected MSI replicates from SR and BR showed a distinctly different community structure compared to the Barents Sea control replicates. $H^{\prime}$ was significantly ( $\mathrm{p} \leq 0.01$ ) lower at MSI replicates $($ mean $\pm \mathrm{SE}=1.83 \pm 0.43$ vs. $3.01 \pm 0.06)$. $J^{\prime}$ was also significantly ( $\left.\mathrm{p} \leq 0.05\right)$ lower at MSI replicates compared to controls $($ mean $=0.43 \pm 0.096$ vs. $0.73 \pm 0.019)$, whereas overall abundance was significantly ( $\mathrm{p} \leq 0.01$ ) higher at the $4 \mathrm{MSI}$ replicates $($ mean $=1657 \pm 442$ vs. $530 \pm$ $470.1 \mathrm{~m}^{-2}$ ).

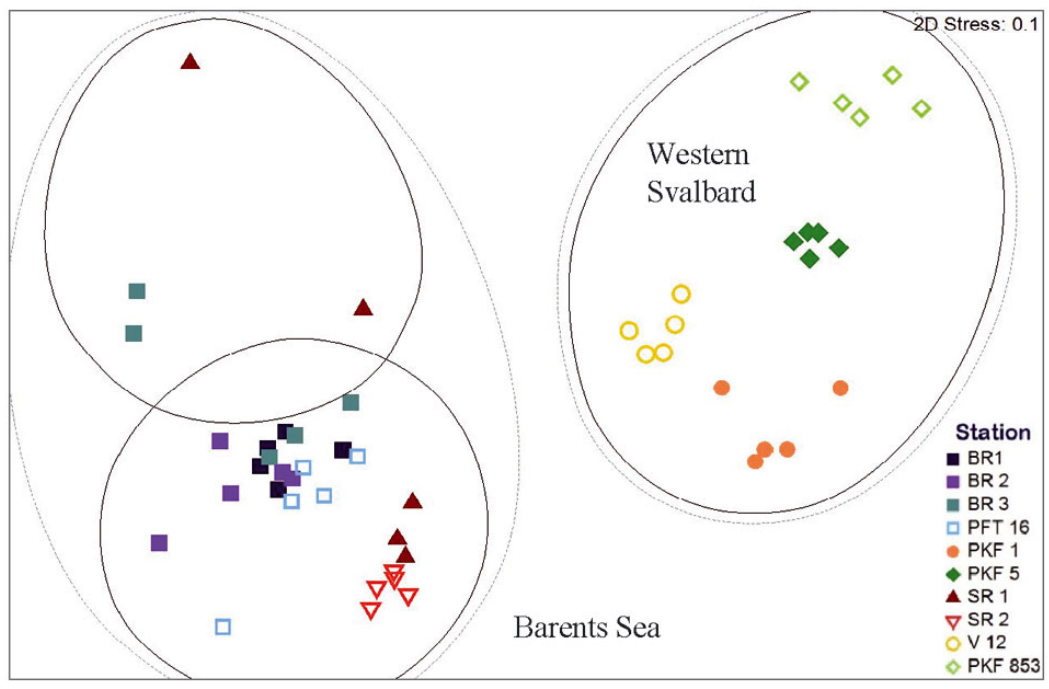

Fig. 6. Non-metric multidimensional scaling plot based on Bray-Curtis similarities of faunal abundances for all replicates. Open symbols: controls; closed symbols: seeps. See Table 1 for station abbreviations. Replicates are separated into 2 main clusters, showing $27 \%$ similarity (dotted lines) separating Barents Sea samples and western Svalbard. Replicates are furthermore separated by a $39 \%$ similarity (solid lines), illustrating the separation of 4 methane-seep influenced replicates from the Barents Sea. See Tables $1 \& 2$ for station information

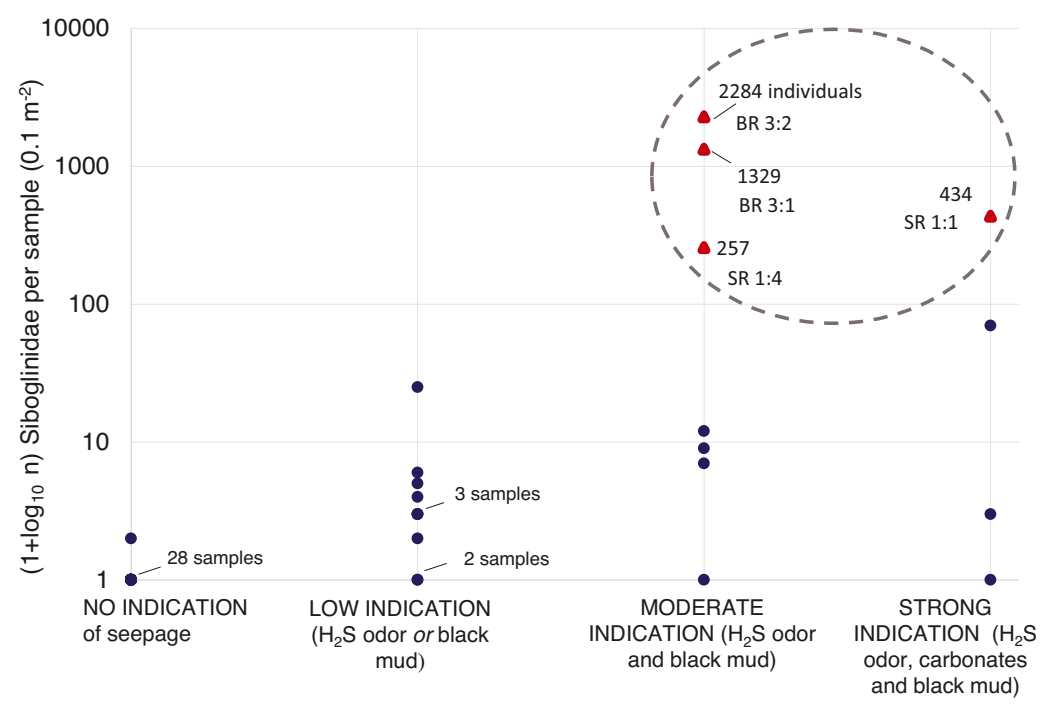

Fig. 7. Characteristics of individual replicates sampled from a priori selected control and seep locations. Seep indicators, viz. sulfide odor, black mud and carbonates ( $x$-axis), in combination with the abundance of Siboglinidae $(1+$ $\left.\log _{10} \mathrm{n}\right)(y$-axis), separates the 4 methane seep-influenced replicates (indicated by red triangles, encircled; numbers are siboglinid density $\left[0.1 \mathrm{~m}^{-2}\right]$ ) from the other replicates in the Barents Sea. See Tables $1 \& 2$ for station information

\section{DISCUSSION}

For the first time, we have documented that methane seepages influence the Arctic benthic faunal communities around Svalbard and in the Barents Sea. Point source seabed methane emissions from individual flares have a strong localized effect on the benthic community structure. Benthic fauna at methane seeps around Svalbard and the Barents Sea differed from control locations in 3 ways: (1) MSI samples had a different species composition, with lower $S$ and $H^{\prime}$ than control sites, (2) biomass was higher at seeps 
Table 6. Pairwise comparison from 2-way ANOVA testing 'region' (BR: Bjørnøyrenna, SR: Storfjordrenna, WS: western Svalbard) within 'impact' (seep vs. control): (a) species richness, (b) Shannon-Wiener diversity index. Significant differences are shown in bold ${ }^{*} \mathrm{p}<0.05,{ }^{* *} \mathrm{p}<0.01,{ }^{* * *} \mathrm{p}<0.001$

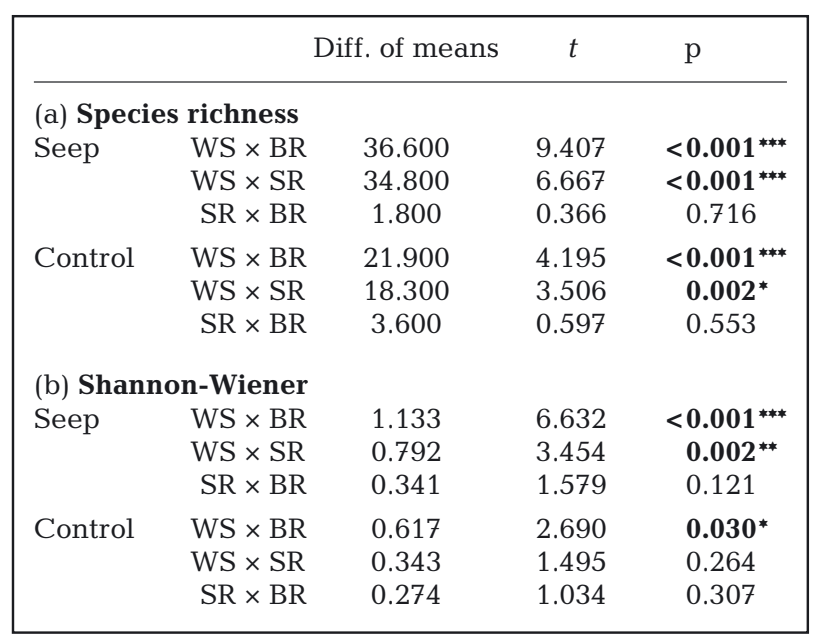

compared to controls, and (3) some seep samples had high densities of chemosymbiotic siboglinid polychaetes. The effects of methane seeps on the benthic community are highly localized, reflecting strong gradients associated with the point source effects of individual seeps. This creates strong heterogeneity within individual methane seep communities. The largest differences among a priori selected seep and control stations were mainly region- and depthdependent, indicating a predominant influence of environmental variables and oceanographic conditions over large spatial scales.

\section{Seep-associated fauna}

Polychaeta was the largest faunal group at all stations and had the highest abundance and biomass, which is similar to other studies examining benthic community structure around Svalbard (WlodarskaKowalczuk \& Pearson 2004, Carroll et al. 2008, Cochrane et al. 2009). Among the top 10 taxa, 8 were polychaetes, of which the most abundant belonged to the family Siboglinidae. Two seep stations were characterized by high abundances of these siboglinid tubeworms (Fig. 8). Siboglinidae is a family of polychaetes with a debated taxonomic history with ranks from phylum Pogonophora (Ivanov 1956) to genus, and which now is considered a family in the order Sabellida (Rouse \& Fauchald 1997, Schulze \& Halanych 2003, Pleijel et al. 2009). Siboglinids commonly occur in reduced environments, hydrothermal vents

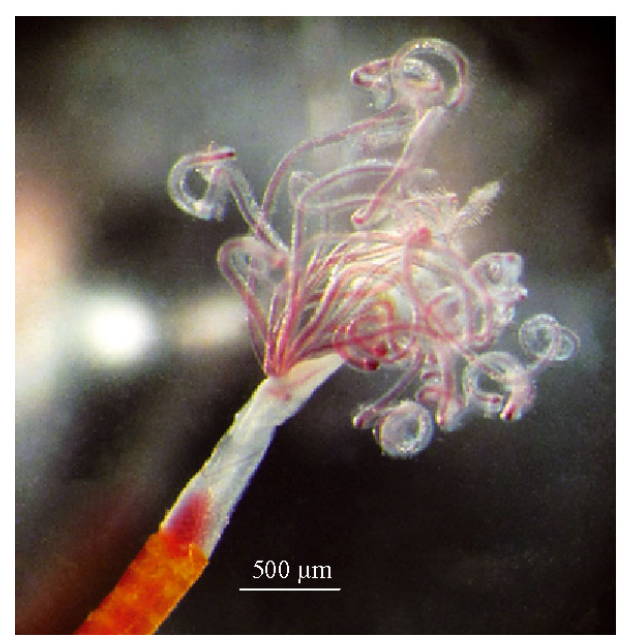

Fig. 8. Living Siboglinidae from the Bjørnøyrenna flare field

and cold seeps where concentrations of reduced chemicals are elevated (Schulze \& Halanych 2003). These polychaetes host chemosynthesizing microbial symbionts in association with sulfur or methane sources. Adult organisms lack a mouth and digestive system and rely on symbiosis with chemoautotroph symbionts for their energetic needs. Species in the clade Frenulata occur from epipelagic to hadal depths (Vinogradova 1997, Southward 2000). They are long and thin (usually $<1 \mathrm{~mm}$ thick), tube-living organisms and are morphologically distinct from their relatives, the vestimentiferans (giant tubeworms), which have rigid tubes and large palps (Southward 2000).

The presence of siboglinids in both SR and BR is a clear sign of seep-influenced habitats. The high densities we observed were most likely connected to a moderate flux of reduced chemicals and suitable soft bottom substrate (Schulze \& Halanych 2003). In WS, we saw almost no seep-associated polychaetes (an exception was a single replicate at PKF 1), despite previous documentation of extensive seepages at PKF (Westbrook et al. 2009, Berndt et al. 2014, Sahling et al. 2014), and confirmation of seeps (elevated concentration of methane, acoustic flares) at the site and time of sampling. The limited abundance of Siboglinidae from our WS samples could be a result of substrate type, where a mixed hard, rocky and sandy bottom typically occurs along the shelf of PKF. Frenulates inhabit soft-bottom habitats, typically burrowing deeply into reduced sediment and keeping their anterior end in overlying bottom water for uptake of oxygen (Southward \& Southward 1982). Quantitative sampling at seeps took place mainly at sites with active flares. The seabed at these sites exhibited a mixed substrate. We attribute the low 
number of siboglinids at PKF, at least to some degree, to the seabed characteristics since the highest number of individuals was recorded in soft muddy sediments.

The most commonly occurring taxon in our study was Mendicula cf. pygmaea, a small $(<2 \mathrm{~mm}$ shell length) bivalve species belonging to the family Thyasiridae. Approximately 100 species of Thyasiridae occur worldwide and commonly inhabit suboxic, anoxic or organic-enriched sediments and environments with hydrocarbon fluids such as cold seeps and vents. Not all thyasirids are chemosynthetic and several degrees of microbial symbiosis have been described within the taxa of this family (Dufour 2005), demonstrating a varying nutritional dependence on symbiosis amongst the chemosynthezising thyasirids (Dando \& Spiro 1993). M. cf. pygmaea is not known to host chemoautotroph symbionts (G. Oliver pers. comm.), but the species has been recorded from hydrocarbon fields in the North Sea and is known from high-Arctic regions (Oliver et al. 2002). We do not specifically associate the high densities of $M$. cf. pygmaea to the cold seeps themselves considering the outcome of our sampling: $M$. cf. pygmaea was present in almost all (47 of 50) replicates with an average of 94 ind. $0.1 \mathrm{~m}^{-2}$. It occurred in the same proportion (13.2\%) at seep and control stations (Table 3), although fewer $M$. cf. pygmaea were seen in the shallow, rocky sites off PKF than at other sites. Its presence, however, in high densities at seeps in our study, sometimes co-occurring with Siboglinidae, suggests that this species can at least tolerate seep environments, if not derive some benefit from living there.

\section{Environmental variables}

Benthic fauna had a spatial pattern that was consistent with our a priori expectations, namely that the strongest differences would be at the regional scale (Table 4, Fig. 5). We attribute the large-scale faunal patterns between WS and the Barents Sea to distinct oceanographic features and seabed characteristics in these regions. WS is predominantly influenced by the West Spitsbergen Current, a warm Atlantic water mass that fills the fjords on the west coast of Spitsbergen in some years (Svendsen et al. 2002, Berge et al. 2005). In contrast, the Barents Sea is influenced by a mix of several water masses, i.e. warm Atlantic waters, Arctic water and locally produced brine water, resulting in hydrographic characteristics that vary in time and with changing bathymetry due to topographic steering of water masses (Johannessen \& Foster 1978, Harris et al. 1998, Skogseth et al. 2005). Sediment characteristics follow these oceanographic patterns and depth, with a high proportion of fine sediments $(72.0-88.5 \%$ pelite, Table 2$)$ in the Barents Sea (Ingvaldsen \& Loeng 2009), and a coarser grain size (17.5-33.7\% pelite, Table 2$)$ in WS. The higher proportion of coarse sediments in WS affects the overall faunal composition, and in particular influences the habitat and distribution of chemosymbiotic siboglinid polychaetes above $200 \mathrm{~m}$ water depth at seeps off the PKF shelf.

In combination with regional differences in oceanographic patterns and sediment type, depth-related primary production and pelagic-benthic coupling are key factors determining benthic community structure. Generally, a faunal community transition occurs from shallow-water ecosystems to deep-sea environments worldwide. The faunal composition in the deeper seas is influenced by limited light and a reduced quantity and quality of organic matter reaching the seafloor (Rex 1981, Gage \& Tyler 1991, Renaud et al. 2008). Similarly, this also occurs at seeps, where a shift between shallow-water and deep-sea ecosystems takes place in the zone of approximately $200 \mathrm{~m}$ water depth (Little et al. 2002, Tarasov et al. 2005, Dubilier et al. 2008). Deep-water cold seeps (>200 m depth) differ in faunal characteristics compared to shallow seeps (Sahling et al. 2003, Levin 2005, Tarasov et al. 2005, Dando 2010). Seep obligate or symbiont-bearing taxa are absent or poorly represented in shallow-water seeps (Sahling et al. 2003, Levin 2005) and there is typically a large subset of surrounding (heterotrophic and conventional) fauna represented at these locations (Dando et al. 1991, Jensen et al. 1992, Levin et al. 2000).

At shallower depths, material from photosynthetic primary production has a shorter settling distance to reach seafloor habitats. This connectivity between the euphotic zone and the seabed (i.e. pelagic-benthic coupling) generally leads to a larger proportion of photosynthetically derived carbon at the seabed and supports higher abundances and biomass of benthic consumers compared to deep-sea benthos. Likewise, at shallow cold seeps, chemosynthetic processes in the water column and seabed will be accompanied by more photoautotrophic production compared to deeper sites where the proportion of primary production reaching the bottom is lower. In the present study, we measured higher concentrations of sedimentary pigments at the shallower sites and pigment concentrations were negatively correlated with depth. Furthermore, faunal biomass was highest in the 2 
shallowest stations at WS but with no correlation to the concentration of benthic pigments.

Our results support that chemosynthesis may not be a favorable strategy in an environment with a relatively large supply of photosynthetically derived carbon to the seafloor. In such environments, the costs of the complex mutualistic adaptations necessary to meet the requirements of chemosynthetic metabolism or symbiosis (Cavanaugh et al. 2006) may outweigh the benefits of the chemosynthetic trophic pathway (Dando 2010). We conclude that the low abundance of chemosynthetic fauna at WS cold seeps is likely due to the combined effects of bottom substrate and that chemosynthesis is not an advantageous life strategy in shallow cold seeps supported by photosynthetically derived organic matter (Dando 2010).

\section{Regional comparisons}

Community structure and faunal parameters at control stations agree with patterns identified in previous studies from both the Barents Sea and Svalbard fjords (Wlodarska-Kowalczuk \& Pearson 2004, Carroll et al. 2008, Cochrane et al. 2009). A main finding of this study is that large regional differences, combined with high within-station variability in faunal parameters at a priori selected seep stations, partially obscure the impact of cold seep environmental conditions on faunal structure. In general, the largest difference in faunal community structure was observed between regions (Table 5a), which was anticipated given that the local environmental conditions along the WS margin differ substantially from the Barents Sea with respect to water current regimes, bottom substrate and depth.

Regionally, a difference in species richness occurs between a priori selected seeps and controls from WS, where seep samples contained a higher number of taxa than control stations. This result was not seen in the Barents Sea, where $H^{\prime}$ or $S$ did not differ between a priori selected seeps and controls. In the a priori selected seep stations from the Barents Sea (BR and SR), we measured both a significantly lower $H^{\prime}$ and lower $S$ compared to the seeps at WS (Table 6). The same pattern was also seen at controls for $S$; WS had a significantly higher number of species than SR and BR controls. However, comparing $H^{\prime}$ between controls, a significant difference was only evident between WS and BR. These contrasting results are mainly explained by the previously discussed regional differences. Nevertheless, the difference in $H^{\prime}$ between controls and seeps at SR compared to WS suggests that the lower $H^{\prime}$ at SR seeps may reflect characteristic differences in seep habitats.

Seeps may increase local biodiversity by adding habitat heterogeneity as substrate and by enhancing food availability in benthic communities via autochthonous chemosynthetic production (Jensen et al. 1992, Sibuet \& Olu 1998, Cordes et al. 2010). The level of seep-based disturbance leading to exclusion of conventional taxa may be examined by comparing the taxa present at predefined seep stations and control stations with the full list of taxa. From the total 400 identified taxa in the entire dataset, 78 were absent at a priori seeps, whereas 108 did not occur at controls. Hence, fewer taxa were absent from the seeps compared to the controls. This pattern is consistent with the intermediate disturbance hypothesis (Connell 1978), which infers that the highest diversity will be found in areas subjected to intermediate levels of disturbance, implying that no species can dominate the community.

On the other hand, environmental stressors such as strong chemical gradients, which are typically seen at vents and seeps, might lead to decreased diversity if the community is dominated by fewer, specialized taxa (Warwick \& Clarke 1995, Turnipseed et al. 2003, Bernardino et al. 2012). Chemical properties in sediments and the overlying water column may constrain the number of colonizing species to highly tolerant forms. High levels of hydrogen sulfide $\left(\mathrm{H}_{2} \mathrm{~S}\right)$ in the sediment is a controlling factor that could result in a reduction in species diversity (Vismann 1991). This favors specialized seep- and vent-associated fauna or species that have adapted to tolerate high concentrations of $\mathrm{H}_{2} \mathrm{~S}$ (Vismann 1991, Dando 2010, Bernardino et al. 2012). Bivalves, polychaetes and crustaceans hosting endosymbiotic microbes are typical seepand vent-associated fauna, tolerating elevated concentration of $\mathrm{H}_{2} \mathrm{~S}$ and allowing them to thrive at high densities (Vrijenhoek 2010). The lower diversity in Barents Sea seeps, especially in the 4 MSI replicates (2 from SR 1 and 2 from BR 3), showed a characteristic indication of habitat disturbance and substantial patchiness within the seep stations. All of the top 5 taxa from these 4 strongly affected replicates, Siboglinidae, Capitella capitata (Fabricius, 1780), Cossura longocirrata Webster \& Benedict, 1887, Spiochateopterus typicus, and Mendicula cf. pygmea, all of which are Polychaeta except the latter (which belongs to the Mollusca) are known to inhabit reduced environments and organic-enriched sediments (Oliver et al. 2002, Włodarska-Kowalczuk et al. 2007, Sweetman et al. 2014, Smith et al. 2015). Similar to other 
types of disturbance sources (e.g. organic or chemical pollution and glaciomarine sedimentation), seepassociated benthic communities may respond in a similar manner to external environmental disturbance, forming assemblages with low diversity and high abundances of a few tolerant species (Pearson \& Rosenberg 1978, Sahling et al. 2002, WlodarskaKowalczuk \& Pearson 2004). Sahling et al. (2002) and Levin et al. (2003) suggested that lower diversity of macrofaunal assemblages is seen in seep communities associated with sediments enriched in sulfide or covered by thiotrophic microbial mats.

Overall, we found a strong significant difference in biomass between seeps and control samples, with seeps supporting higher biomass than nearby control areas. This finding is consistent with previous studies of cold seep habitats (Olu et al. 1996, Sahling et al. 2002, Sibuet \& Roy 2003). A higher local biomass is characteristic of many chemosynthetic environments, including the HMMV in the Barents Sea, where assemblages of bivalves and tubeworm fields have been documented to attract vagrant heterotrophic fauna (Gebruk et al. 2003, Vanreusel et al. 2009). The within-station variability that was observed at the seep stations is likely the result of 2 factors: the localized effect of the point source methane seep, and the sampling abilities of our vessel and equipment. Visual observations of black mud, sulfide odor and carbonate crust, combined with the results of the nMDS cluster analysis (Figs. 6 \& 7) demonstrate that sampling was directly on target for a few replicates at the seep, whereas in others, sampling was likely in a peripheral zone of seepage (BR 1 and BR 2). It also suggests that the primary zone of effect from any single cold seep (Fig. 3) is relatively limited and localized (on a scale of meters).

Our observations may be compared to the faunal community structure at the HMMV where different faunal zones radiate outwards from the mud volcano (Gebruk et al. 2003, Lösekann et al. 2007, Vanreusel et al. 2009). Microbial mats on the seabed are widespread at the center of the mud volcano. Away from the point source, chemosymbiotic fauna such as clams and tubeworms dominate, with conventional heterotrophic fauna becoming more common in the outer periphery. Bowden et al. (2013) documented substantial regional differences in cold seep community structure at the Hikurangi Margin (New Zealand) depending on bottom substrate. Three main habitats were identified in that study: (1) carbonate rocks with epifauna (scleractinian corals and mainly non-chemosynthetic fauna), (2) beds of Vesicomyidae clams and high densities of other chemosynthetic associated fauna (ampharetid tubeworms and bathymodiolin mussels) and (3) microbial mats with absence of other mega- and epifauna.

The benthic macrofaunal community structure at the cold seeps of high-Arctic shelves (this study), the HMMV and the seeps at the Hikurangi Margin have a number of patterns in common, including high variability within seep stations, large regional differences and high densities of seep-associated fauna at a few sites (Milkov et al. 1999, Gebruk et al. 2003, Bowden et al. 2013). Bottom substrate is most likely a strong driver of community patterns in cold seep ecosystems and, together with the seepage of hydrocarbons, determines the spatial extent of the seep influence. A recent study from another active deep (1200 m) methane hydrate system in the high-Arctic, Vestnesa Ridge $\left(79^{\circ} \mathrm{N}\right)$, documented paleo seep communities of chemo-obligate Vesicomyidae bivalves (Ambrose et al. 2015). Bivalve assemblages were locally established through $1000 \mathrm{yr}$ of focused methane seepage. After a millennium of emissions, the seep intensity decreased because of an inferred insufficient flow of chemicals to support the community (Ambrose et al. 2015). The evolution of this paleo seep-associated bivalve assemblage is similar to the successional model of Bowden et al. (2013).

Our study reveals high heterogeneity at cold seeps with small-scale local effects despite high concentrations of methane in the water column over larger areas (Steinle et al. 2015, Lund Myhre et al. 2016). The combined faunal impact of multiple seeps clustered in a larger seep field is still uncertain for our study area. Future studies are needed in order to determine the connectivity among different cold seep habitats and to examine large-scale spatial and temporal changes of methane release and the concomitant influences on Arctic benthos. Further, the cold ocean temperatures of the Arctic allow formation of methane hydrate at shallower water depths than at lower latitudes (Weaver \& Stewart 1982, Kvenvolden 1994). Destabilization of hydrates could occur as the environment for stable methane hydrates (requiring high pressure and low temperature) at the shallow shelf areas in Svalbard is under change because of ocean warming (MarínMoreno et al. 2013, Graves et al. 2015). The cold seep communities in our study are aligned with the depth of the gas hydrate stability zone in Svalbard (Rajan et al. 2012, Portnov et al. 2016), suggesting that warming of this region may lead to increased methane emissions from dissociating hydrates. The benthic ecological impacts of such an input of 
methane are currently unknown, but the existing information on cold seep faunal communities is a key baseline from which we can gauge future changes to the system.

\section{CONCLUSIONS}

Examination of the faunal structure at Arctic shelf areas $<360 \mathrm{~m}$ influenced by methane seeps from the western Svalbard shelf and the Barents Sea indicates that large-scale differences exist between regions, most likely because of the distinct oceanographic settings. We demonstrate that cold seeps have a strong impact on Arctic benthic systems, but at localized scales. Generally, faunal characteristics at seep habitats are patchy, suggesting small-scale heterogeneity in the environment surrounding the cold seeps. Biomass is remarkably higher at seeps compared to controls, regardless of region. Records of high densities of seep-associated fauna, such as siboglinid tubeworms, also demonstrate a chemosynthetic impact on benthos. We conclude that the overall faunal patterns we observed in this study result from a combination of large-scale (regional) environmental influences such as water mass and depth, and from the direct influence of methane discharge from the seafloor. The strong community-level effects caused by focused methane emissions are currently concentrated in a small area (meter scale) surrounding sites where seepage occurs, initiating heterogeneity and localized patchiness to Arctic benthos. Future ocean warming may increase melting of hydrates, leading to more widespread methane release that will influence benthic communities on a much larger scale than we observed.

Acknowledgements. This work was funded through the Centre for Arctic Gas Hydrate, Environment and Climate (CAGE) and the Research Council of Norway through its Centers of Excellence funding scheme, project number 223259. We acknowledge the captain and crew onboard RV 'Helmer Hanssen' and the cruise leaders S. Büenz, K. Andreassen, and G. Panieri. Thanks to sorters and taxonomic specialists at the biological laboratory at Akvaplanniva, Tromsø, for processing samples. We are grateful for the work of P. Serov in processing the seismic data and sample coordinates to create Fig. 3, and to G. Oliver for discussions about thyasirid bivalve taxonomy. Thanks to J. Mienert and P. Renaud for discussions on earlier drafts of the manuscript and to 2 anonymous reviewers for perceptive comments that helped refine the final manuscript. W.G.A. is now an employee of the US NSF; however, any opinions, findings, conclusions, or recommendations expressed in this material are those of W.G.A. and his coauthors, and do not necessarily reflect the views of the US NSF.

\section{LITERATURE CITED}

Ambrose WG Jr, Panieri G, Schneider A, Plaza-Faverola A and others (2015) Bivalve shell horizons in seafloor pockmarks of the last glacial-interglacial transition: a thousand years of methane emissions in the Arctic Ocean. Geochem Geophys Geosyst 16:4108-4129

Andreassen K (2013) Cruise report-marine geological cruise to Storfjordrenna and Bjørnøyrenna. Institute of Geology, Faculty of Science, University of Tromsø, Tromsø

Andreassen K, Winsborrow M (2009) Signature of ice streaming in Bjørnøyrenna, Polar North Atlantic, through the Pleistocene and implications for ice-stream dynamics. Ann Glaciol 50:17-26

Bale A, Kenny A (2005) Sediment analysis and seabed characterisation. In: Eleftheriou A, McIntyre A (eds) Methods for the study of marine benthos. Blackwell Publishing, Oxford, p 43-87

Berge J, Johnsen G, Nilsen F, Gulliksen B, Slagstad D (2005) Ocean temperature oscillations enable reappearance of blue mussels Mytilus edulis in Svalbard after a 1000 year absence. Mar Ecol Prog Ser 303:167-175

> Berge J, Renaud PE, Darnis G, Cottier F and others (2015) In the dark: a review of ecosystem processes during the Arctic polar night. Prog Oceanogr 139:258-271

Bernardino AF, Levin LA, Thurber AR, Smith CR (2012) Comparative composition, diversity and trophic ecology of sediment macrofauna at vents, seeps and organic falls. PLoS ONE 7:e33515

Berndt C, Feseker T, Treude T, Krastel S and others (2014) Temporal constraints on hydrate-controlled methane seepage off Svalbard. Science 343:284-287

> Boetius A, Suess E (2004) Hydrate Ridge: a natural laboratory for the study of microbial life fueled by methane from near-surface gas hydrates. Chem Geol 205:291-310

Boetius A, Wenzhofer F (2013) Seafloor oxygen consumption fuelled by methane from cold seeps. Nat Geosci 6 : 725-734

Bohrmann G, Greinert J, Suess E, Torres M (1998) Authigenic carbonates from the Cascadia subduction zone and their relation to gas hydrate stability. Geology 26: $647-650$

> Bowden DA, Rowden AA, Thurber AR, Baco AR, Levin LA, Smith CR (2013) Cold seep epifaunal communities on the Hikurangi Margin, New Zealand: composition, succession, and vulnerability to human activities. PLoS ONE 8: e76869

- Carroll ML, Denisenko SG, Renaud PE, Ambrose WG Jr (2008) Benthic infauna of the seasonally ice-covered western Barents Sea: patterns and relationships to environmental forcing. Deep-Sea Res II 55:2340-2351

Cavanaugh CM, McKiness ZP, Newton IL, Stewart FJ (2006) Marine chemosynthetic symbioses. In: Dworkin $M$, Falkow S, Rosenberg E, Schleifer KH, Stackebrandt E (eds) The prokaryotes. Springer, New York, NY, p 475-507

> Clarke KR (1993) Non-parametric multivariate analysis of changes in community structure. Aust J Ecol 18:117-143

Clarke KR, Gorley RN (2006) PRIMER v6: user manual/ tutorial. PRIMER-E, Plymouth

> Cochrane SK, Denisenko SG, Renaud PE, Emblow CS, Ambrose WG Jr, Ellingsen IH, Skarðhamar J (2009) Benthic macrofauna and productivity regimes in the Barents Sea-ecological implications in a changing Arctic. J Sea Res 61:222-233

Connell JH (1978) Diversity in tropical rain forests and coral 
reefs. Science 199:1302-1310

Cordes EE, Cunha MR, Galeron J, Mora C and others (2010) The influence of geological, geochemical, and biogenic habitat heterogeneity on seep biodiversity. Mar Ecol 31: 51-65

Dando PR (2010) Biological communities at marine shallowwater vent and seep sites. In: Steffen K (ed) The vent and seep biota. Springer, Dordrecht, p 333-378

> Dando PR, Spiro B (1993) Varying nutritional dependence of the thyasirid bivalves Thyasira sarsi and T. equalis on chemoautotrophic symbiotic bacteria, demonstrated by isotope ratios of tissue carbon and shell carbonate. Mar Ecol Prog Ser 92:151-158

Dando PR, Austen MC, Burke RA Jr, Kendall MA and others (1991) Ecology of a North Sea pockmark with an active methane seep. Mar Ecol Prog Ser 70:49-63

> Decker C, Morineaux M, Van Gaever S, Caprais JC and others (2012) Habitat heterogeneity influences cold seep macrofaunal communities within and among seeps along the Norwegian margin. Part 1: macrofaunal community structure. Mar Ecol 33:205-230

> Dowdeswell JA, Hogan K, Evans J, Noormets R, Cofaigh CÓ, Ottesen D (2010) Past ice-sheet flow east of Svalbard inferred from streamlined subglacial landforms. Geology 38:163-166

> Dubilier N, Bergin C, Lott C (2008) Symbiotic diversity in marine animals: the art of harnessing chemosynthesis. Nat Rev Microbiol 6:725-740

Dufour SC (2005) Gill anatomy and the evolution of symbiosis in the bivalve family Thyasiridae. Biol Bull 208: 200-212

Ferré B, Mienert J, Feseker T (2012) Ocean temperature variability for the past 60 years on the Norwegian Svalbard margin influences gas hydrate stability on human time scales. J Geophys Res 117:C10017, doi:10.1029/ 2012JC008300

Foucher JP, Westbrook G, Boetius A, Ceramicola S and others (2009) Structure and drivers of cold seep ecosystems. Oceanography 22:92-109

Gage JD, Tyler PA (1991) Deep-sea biology: a natural history of organisms at the deep-sea floor. Cambridge University Press, Cambridge

> Gebruk AV, Krylova EM, Lein AY, Vinogradov GM and others (2003) Methane seep community of the Håkon Mosby mud volcano (the Norwegian Sea): composition and trophic aspects. Sarsia 88:394-403

Gentz T, Damm E, Schneider von Deimling J, Mau S, McGinnis DF, Schlüter M (2014) A water column study of methane around gas flares located at the West Spitsbergen continental margin. Cont Shelf Res 72:107-118

Graves CA, Steinle L, Rehder G, Niemann H and others (2015) Fluxes and fate of dissolved methane released at the seafloor at the landward limit of the gas hydrate stability zone offshore western Svalbard. J Geophys Res 120:6185-6201

Harris C, Plueddemann A, Gawarkiewicz G (1998) Water mass distribution and polar front structure in the western Barents Sea. J Geophys Res 103:2905-2917

Holm-Hansen O, Lorenzen CJ, Holmes RW, Strickland JDH (1965) Fluorometric determination of chlorophyll. J Cons Int Explor Mer 30:3-15

Hunter SJ, Goldobin DS, Haywood AM, Ridgwell A, Rees JG (2013) Sensitivity of the global submarine hydrate inventory to scenarios of future climate change. Earth Planet Sci Lett 367:105-115
Ingvaldsen RB, Loeng $H$ (2009) Physical oceanography. In: Sakshaug E, Johnsen G, Kovacs KM (eds) Ecosystem Barents Sea. Tapir Academic Press, Trondheim, p 33-64

> Ivanov A (1956) On the systematic position of Pogonophora. Syst Zool 5:165-173

Jakobsson M, Mayer L, Coakley B, Dowdeswell JA and others (2012) The international bathymetric chart of the Arctic Ocean (IBCAO) version 3.0. Geophys Res Lett 39:L12609, doi:10.1029/2012GL055219

> Jensen P, Aagaard I, Burke RA Jr, Dando PR and others (1992) 'Bubbling reefs' in the Kattegat: submarine landscapes of carbonate-cemented rocks support a diverse ecosystem at methane seeps. Mar Ecol Prog Ser 83: $103-112$

Johannessen OM, Foster L (1978) A note on the topographically controlled oceanic polar front in the Barents Sea. J Geophys Res 83:4567-4571

Kędra M, Renaud PE, Andrade H, Goszczko I, Ambrose WG Jr (2013) Benthic community structure, diversity, and productivity in the shallow Barents Sea bank (Svalbard Bank). Mar Biol 160:805-819

> Kvenvolden KA (1994) Natural gas hydrate occurrence and issues. Ann N Y Acad Sci 715:232-246

Lashof DA, Ahuja DR (1990) Relative contributions of greenhouse gas emissions to global warming. Nature 344: 529-531

Lein A, Vogt P, Crane K, Egorov A, Ivanov M (1999) Chemical and isotopic evidence for the nature of the fluid in $\mathrm{CH}_{4}$-containing sediments of the Håkon Mosby Mud Volcano. Geo-Mar Lett 19:76-83

Levin L (2005) Ecology of cold seep sediments: interactions of fauna with flow, chemistry and microbes. Oceanogr Mar Biol Annu Rev 43:1-46

Levin LA, James DW, Martin CM, Rathburn AE, Harris LH, Michener RH (2000) Do methane seeps support distinct macrofaunal assemblages? Observations on community structure and nutrition from the northern California slope and shelf. Mar Ecol Prog Ser 208:21-39

Levin LA, Ziebis W, Mendoza GF, Growney VA and others (2003) Spatial heterogeneity of macrofauna at northern California methane seeps: influence of sulfide concentration and fluid flow. Mar Ecol Prog Ser 265:123-139

Little CT, Campbell KA, Herrington RJ (2002) Why did ancient chemosynthetic seep and vent assemblages occur in shallower water than they do today? Comment. Int J Earth Sci 91:149-153

Lønne O, Gulliksen B (1991) Sympagic macro-fauna from multiyear sea-ice near Svalbard. Polar Biol 11:471-477

Lösekann T, Knittel K, Nadalig T, Fuchs B, Niemann H, Boetius A, Amann R (2007) Diversity and abundance of aerobic and anaerobic methane oxidizers at the Haakon Mosby Mud Volcano, Barents Sea. Appl Environ Microbiol 73:3348-3362

Lund Myhre C, Ferré B, Platt SM, Silyakova A and others (2016) Extensive release of methane from Arctic seabed west of Svalbard during summer 2014 does not influence the atmosphere. Geophys Res Lett 43:4624-4631

> MacDonald GJ (1990) Role of methane clathrates in past and future climates. Clim Change 16:247-281

> Marín-Moreno H, Minshull TA, Westbrook GK, Sinha B, Sarkar S (2013) The response of methane hydrate beneath the seabed offshore Svalbard to ocean warming during the next three centuries. Geophys Res Lett 40: 5159-5163

Milkov A, Vogt P, Cherkashev G, Ginsburg G, Chernova N, 
Andriashev A (1999) Sea-floor terrains of Håkon Mosby Mud Volcano as surveyed by deep-tow video and still photography. Geo-Mar Lett 19:38-47

Niemann H, Lösekann T, de Beer D, Elvert M and others (2006) Novel microbial communities of the Haakon Mosby mud volcano and their role as a methane sink. Nature 443:854-858

Oliver PG, Killeen IJ, Ockelmann KW (2002) The Thyasiridae (Mollusca: Bivalvia) of the British continental shelf and North Sea oil fields: an identification manual. National Museums \& Galleries of Wales, Cardiff

Olu K, Duperret A, Sibuet M, Foucher JP, Fiala-Médioni A (1996) Structure and distribution of cold seep communities along the Peruvian active margin: relationship to geological and fluid patterns. Mar Ecol Prog Ser 132: 109-125

Patton $\mathrm{H}$, Andreassen $\mathrm{K}$, Bjarnadóttir LR, Dowdeswell JA and others (2015) Geophysical constraints on the dynamics and retreat of the Barents Sea ice sheet as a paleobenchmark for models of marine ice sheet deglaciation. Rev Geophys 53:1051-1098

Pearson T, Rosenberg R (1978) Macrobenthic succession in relation to organic enrichment and pollution of the marine environment. Oceanogr Mar Biol Annu Rev 16: 229-311

Pleijel F, Dahlgren TG, Rouse GW (2009) Progress in systematics: from Siboglinidae to Pogonophora and Vestimentifera and back to Siboglinidae. C R Biol 332: $140-148$

Portnov A, Vadakkepuliyambatta S, Mienert J, Hubbard A (2016) Ice-sheet-driven methane storage and release in the Arctic. Nat Commun 7:10314

Rajan A, Mienert J, Bünz S (2012) Acoustic evidence for a gas migration and release system in Arctic glaciated continental margins offshore NW-Svalbard. Mar Pet Geol 32:36-49

Renaud PE, Morata N, Carroll ML, Denisenko SG, Reigstad M (2008) Pelagic-benthic coupling in the western Barents Sea: processes and time scales. Deep-Sea Res II 55: 2372-2380

Rex MA (1981) Community structure in the deep-sea benthos. Annu Rev Ecol Syst 12:331-353

Rouse GW, Fauchald K (1997) Cladistics and polychaetes. Zool Scr 26:139-204

Ruppel C (2011) Methane hydrates and contemporary climate change. Nature Educ Knowledge 3:29

Sahling H, Rickert D, Lee RW, Linke P, Suess E (2002) Macrofaunal community structure and sulfide flux at gas hydrate deposits from the Cascadia convergent margin, NE Pacific. Mar Ecol Prog Ser 231:121-138

Sahling H, Galkin SV, Salyuk A, Greinert J, Foerstel H, Piepenburg D, Suess E (2003) Depth-related structure and ecological significance of cold-seep communitiesa case study from the Sea of Okhotsk. Deep-Sea Res I 50: 1391-1409

Sahling H, Römer M, Pape T, Bergès B and others (2014) Gas emissions at the continental margin west of Svalbard: mapping, sampling, and quantification. Biogeosciences 11:6029-6046

Schulze A, Halanych KM (2003) Siboglinid evolution shaped by habitat preference and sulfide tolerance. Hydrobiologia 496:199-205

Sibuet M, Olu K (1998) Biogeography, biodiversity and fluid dependence of deep-sea cold-seep communities at active and passive margins. Deep-Sea Res II 45:517-567
Sibuet M, Roy KOL (2003) Cold seep communities on continental margins: structure and quantitative distribution relative to geological and fluid venting patterns. In: Wefer G, Billett D, Hebbeln D, Jørgensen B, Schlüter M, van Weering TE (eds) Ocean margin systems. Springer, Berlin, p 235-251

> Skogseth R, Haugan P, Jakobsson M (2005) Watermass transformations in Storfjorden. Cont Shelf Res 25: 667-695

Smith CR, Glover AG, Treude T, Higgs ND, Amon DJ (2015) Whale-fall ecosystems: recent insights into ecology, paleoecology, and evolution. Annu Rev Mar Sci 7:571-596

Solheim A, Elverhøi A (1993) Gas-related sea floor craters in the Barents Sea. Geo-Mar Lett 13:235-243

> Søreide JE, Carroll ML, Hop H, Ambrose WG Jr, Hegseth EN, Falk-Petersen S (2013) Sympagic-pelagic-benthic coupling in Arctic and Atlantic waters around Svalbard revealed by stable isotopic and fatty acid tracers. Mar Biol Res 9:831-850

Southward EC (2000) Class Pogonophora. In: Beesley PL, Ross GJB, Glasby CJ (eds) Polychaetes \& allies: the southern synthesis. Fauna of Australia Vol 4A. CSIRO Publishing, Melbourne, p 331-351

Southward AJ, Southward EC (1982) The role of dissolved organic matter in the nutrition of deep-sea benthos. Am Zool 22:647-659

Steinle L, Graves CA, Treude T, Ferré B and others (2015) Water column methanotrophy controlled by a rapid oceanographic switch. Nat Geosci 8:378-382

Svendsen H, Beszczynska Møller A, Hagen JO, Lefauconnier B and others (2002) The physical environment of Kongsfjorden-Krossfjorden, an Arctic fjord system in Svalbard. Polar Res 21:133-166

Sweetman AK, Norling K, Gunderstad C, Haugland BT, Dale T (2014) Benthic ecosystem functioning beneath fish farms in different hydrodynamic environments. Limnol Oceanogr 59:1139-1151

- Tarasov V, Gebruk A, Mironov A, Moskalev L (2005) Deepsea and shallow-water hydrothermal vent communities: two different phenomena? Chem Geol 224:5-39

> Thurber AR, Levin LA, Rowden AA, Sommer S, Linke P, Kröger K (2013) Microbes, macrofauna, and methane: a novel seep community fueled by aerobic methanotrophy. Limnol Oceanogr 58:1640-1656

Turnipseed M, Knick K, Lipcius R, Dreyer J, Van Dover C (2003) Diversity in mussel beds at deep sea hydrothermal vents and cold seeps. Ecol Lett 6:518-523

Van Dover C (2000) The ecology of deep-sea hydrothermal vents. Princeton University Press, Princeton, NJ

> Vanreusel A, Andersen AC, Boetius A, Connelly D and others (2009) Biodiversity of cold seep ecosystems along the European margins. Oceanography 22:110-127

- Vinogradova N (1997) Zoogeography of the abyssal and hadal zones. Adv Mar Biol 32:325-387

Vismann B (1991) Sulfide tolerance: physiological mechanisms and ecological implications. Ophelia 34:1-27

Vogt P, Cherkashev G, Ginsburg G, Ivanov G and others (1997) Haakon Mosby mud volcano provides unusual example of venting. Eos Trans AGU 78:549-557

Vrijenhoek CR (2010) Genetics and evolution of deep-sea chemosynthetic bacteria and their invertebrate hosts. In: Steffen K (ed) The vent and seep biota. Springer, Dordrecht, p 15-49

Warwick RM, Clarke KR (1995) New 'biodiversity' measures reveal a decrease in taxonomic distinctness with increas- 
ing stress. Mar Ecol Prog Ser 129:301-305

Wassmann P, Reigstad M (2011) Future Arctic Ocean seasonal ice zones and implications for pelagic-benthic coupling. Oceanography 24:220-231

Weaver J, Stewart J (1982) In situ hydrates under the Beaufort Sea shelf. In: Proc $4^{\text {th }}$ Can Permafrost Conf, Calgary, p 312-319

Westbrook GK, Thatcher KE, Rohling EJ, Piotrowski AM and others (2009) Escape of methane gas from the seabed along the West Spitsbergen continental margin. Geophys Res Lett 36:L15608, doi:10.1029/2009GL039191

- Wlodarska-Kowalczuk M, Pearson TH (2004) Soft-bottom macrobenthic faunal associations and factors affecting species distributions in an Arctic glacial fjord (Kongsfjord, Spitsbergen). Polar Biol 27:155-167

Wlodarska-Kowalczuk M, Pearson TH, Kendall MA (2005)

Editorial responsibility: James McClintock,

Birmingham, Alabama, USA
Benthic response to chronic natural physical disturbance by glacial sedimentation in an Arctic fjord. Mar Ecol Prog Ser 303:31-41

Włodarska-Kowalczuk M, Szymelfenig M, Zajiczkowski M (2007) Dynamic sedimentary environments of an Arctic glacier-fed river estuary (Adventfjorden, Svalbard). II: Meio-and macrobenthic fauna. Estuar Coast Shelf Sci 74 : 274-284

Zaborska A, Carroll J, Papucci C, Torricelli L, Carroll ML, Walkusz-Miotk J, Pempkowiak J (2008) Recent sediment accumulation rates for the Western margin of the Barents Sea. Deep-Sea Res II 55:2352-2360

Zapata Hernández G, Sellanes J, Thurber AR, Levin LA, Chazalon F, Linke P (2014) New insights on the trophic ecology of bathyal communities from the methane seep area off Concepción, Chile ( 36 $\left.{ }^{\circ} \mathrm{S}\right)$. Mar Ecol 35:1-21

Submitted: January 15, 2016; Accepted: May 12, 2016

Proofs received from author(s): June 13, 2016 